\title{
US Pharma's Financialized Business Model
}

\author{
William Lazonick, Matt Hopkins, Ken Jacobson, \\ Mustafa Erdem Sakinç and Öner Tulum*
}

\author{
Working Paper No. 60
}

July 13, 2017

(revised September 8, 2017)

\begin{abstract}
Price gouging in the US pharmaceutical drug industry goes back more than three decades. In 1985 US Representative Henry Waxman, chair of the House Subcommittee on Health and the Environment, accused the pharmaceutical industry of "gouging the American public" with "outrageous" price increases, driven by "greed on a massive scale." Even in the wake of the many Congressional inquiries that have taken place since the 1980s, including one inspired by the extortionate prices that Gilead Sciences has placed on its Hepatitis-C drugs Sovaldi since 2013 and Harvoni since 2014, the US government has not seen fit to regulate drug prices. UK Prescription Price Regulation Scheme data for

\footnotetext{
* William Lazonick is Professor of Economics, University of Massachusetts Lowell; Visiting Professor, University of Ljubljana; Professeur Associé, Institut Mines-Télécom; Professorial Research Associate, SOAS, University of London; and President, The Academic-Industry Research Network (theAIRnet); Matt Hopkins, Ken Jacobson, Mustafa Erdem Sakinç, and Öner Tulum are researchers at theAIRnet. Jacobson is also theAIRnet communications director. Sakinç completed a $\mathrm{PhD}$ in economics at the University of Bordeaux in 2016 and is a newly appointed assistant professor of economics at University of Paris 13. New Economic Thinking (projects on Collective and Cumulative Careers and Financialization of the US Pharmaceutical Industry), the European Union Horizon 2020 Research and Innovation Programme under grant agreement No. 649186 (ISIGrowth: Innovation-Fuelled Sustainable and Inclusive Growth), and the Ford Foundation (Financial Institutions for Innovation and Development project). For correspondence contactwilliam.lazonick@gmail.com
} Tulum is a PhD student at the University of Ljubljana. Funding for this research came from the Institute for
\end{abstract}


1996 through 2010 show that, while drug prices in other advanced nations were close to the UK's regulated prices, those in the United States were between 74 percent and 181 percent higher. Médecins Sans Frontières (MSF) has produced abundant evidence that US drug prices are by far the highest in the world.

The US pharmaceutical industry's invariable response to demands for price regulation has been that it will kill innovation. US drug companies claim that they need higher prices than those that prevail elsewhere so that the extra profits can be used to augment R\&D spending. The result, they contend, is more drug innovation that benefits the United States, and indeed the whole world. It is a compelling argument, until one looks at how major US pharmaceutical companies actually use the profits that high drug prices generate. In the name of "maximizing shareholder value" (MSV), pharmaceutical companies allocate the profits generated from high drug prices to massive repurchases, or buybacks, of their own corporate stock for the sole purpose of giving manipulative boosts to their stock prices. Incentivizing these buybacks is stock-based compensation that rewards senior executives for stock-price "performance."

Like no other sector, the pharmaceutical industry puts a spotlight on how the political economy of science is a matter of life and death. In this paper, we invoke "the theory of innovative enterprise" to explain how and why high drug prices restrict access to medicines and undermine medical innovation. An innovative enterprise seeks to develop a high-quality product that it can sell to the largest possible market at the most affordable price. In sharp contrast, the MSV-obsessed companies that dominate the US drug industry have become monopolies that restrict output and raise price. These companies need to be regulated.

JEL codes: D22, D24, D40, G35, H51, L10, L21, L51, L65, M52

Keywords: Pharmaceutical drugs, innovation, financialization, price-gouging, stock buybacks, executive pay, shareholder value 


\section{Drug-Price Gouging to "Maximize Shareholder Value"}

The news in September 2015 that the pharmaceutical company Turing, led by a 32-yearold hedge-fund manager, had raised the price of a 62-year-old drug from $\$ 13.50$ to $\$ 750.00$ per dose focused public attention on price gouging in an industry in which the pursuit of wealth has trumped the improvement of health (Pollack 2015). The day after Democratic presidential candidate Hillary Clinton tweeted that this "price gouging" was "outrageous," the NASDAQ Biotechnology Index plunged by 4.7 percent, or $\$ 15$ billion in market capitalization, in a few hours of trading. This reaction demonstrated the importance of the stock market to the fortunes that well-positioned shareholders can reap when pharmaceutical companies can keep drug prices high (Langreth and Armstrong 2015).

The industry trade group Pharmaceutical Researchers and Manufacturers of America (PhRMA) was quick to disown Turing, tweeting that its actions did not "represent the values of PhRMA member companies" (Cha 2015). Yet price gouging in the US pharmaceutical drug industry goes back more than three decades. In 1985 US Representative Henry Waxman (D-CA), chair of the House Subcommittee on Health and the Environment, accused the pharmaceutical industry of "gouging the American public" with "outrageous" price increases, driven by "greed on a massive scale" (Horwitz 1985).

Even in the wake of the many Congressional inquiries that have taken place since the 1980s, including one inspired by the extortionate prices Gilead Sciences has placed on its Hepatitis-C drugs Sovaldi since 2013 and Harvoni since 2014 (United States Senate Committee on Finance 2015), the US government has not seen fit to regulate drug prices. UK Prescription Price Regulation Scheme data for 1996 through 2010 show that, while drug prices in other advanced nations were close to the UK's regulated prices, those in the United States were between 74 percent and 181 percent higher (UK Department of Health 2012, p. 30; see also Kantarjian and Rajkumar 2015). Médecins Sans Frontières (MSF) has produced abundant evidence that US drug prices are by far the highest in the world (Médecins Sans Frontières 2015).

The US pharmaceutical industry's invariable response to demands for price regulation has been that it will kill innovation. US drug companies claim that they need higher prices than those that prevail elsewhere so that the extra profits can be used to augment R\&D spending. The result, they contend, is more drug innovation that benefits the United States and, indeed, the whole world (see for example Kravitz 1985; Horowitz 1987; Pollack 1988; Rovner 1992; Leary 1995; Mossinghoff 1999; Levin 2001; Nordrum 2015).

It is a compelling argument - until one looks at how major US pharmaceutical companies actually use the profits that high drug prices generate. In the name of "maximizing shareholder value" (MSV), pharmaceutical companies allocate profits generated by high drug prices to massive repurchases, or buybacks, of their own corporate stock for the sole purpose of giving manipulative boosts to their stock prices. Incentivizing these buybacks is stock-based compensation that rewards senior executives for increases in their companies' stock prices (Lazonick 2014b; Lazonick 2014c; Lazonick 2015b; Hopkins and Lazonick 2016). 
Like no other sector, the pharmaceutical industry puts a spotlight on how the political economy of science is a matter of life and death. In this paper, we invoke "the theory of innovative enterprise" to explain how and why high drug prices restrict access to medicines and undermine medical innovation. An innovative enterprise seeks to develop a high-quality product that it can sell to the largest possible market at the most affordable price (Lazonick 2015c). In sharp contrast, the MSV-obsessed companies that dominate the US drug industry have become monopolies that restrict output and raise price. This paper exposes the financialized business model that dominates the US pharmaceutical drug industry. From the perspective of the theory of innovative enterprise, we call for a number of policy measures to transform the industry from one that has become the source of concentrations of obscene wealth to one that can enable the world's population to improve their health.

\section{Buyback Boosts to Stock Prices}

US pharma companies claim that high drug prices fund investments in innovation. Yet the 18 drug companies in the S\&P 500 Index in January 2016 and publicly listed from 2006 through 2015 distributed 99 percent of their profits to shareholders over the decade, 50 percent as buybacks and 49 percent as dividends (see Table 1).

Table 1. Stock buybacks and cash dividends, 2006-2015, at 18 US pharmaceutical companies in the S\&P 500 Index in January 2016

\begin{tabular}{|c|c|c|c|c|c|c|c|c|c|c|}
\hline Company & $\begin{array}{c}\text { REV, } \\
\$ \text { \$b }\end{array}$ & $\begin{array}{l}\text { NI, } \\
\$ b\end{array}$ & $\begin{array}{c}\text { BB, } \\
\text { \$b }\end{array}$ & $\begin{array}{l}\text { DV, } \\
\text { \$b }\end{array}$ & $\begin{array}{c}\text { R\&D, } \\
\$ b\end{array}$ & $\begin{array}{c}\text { BB/NI } \\
\%\end{array}$ & \begin{tabular}{|c|} 
DV/NI \\
$\%$
\end{tabular} & $\begin{array}{c}(\mathrm{BB}+\mathrm{DV}) / \\
\mathrm{NI} \%\end{array}$ & \begin{tabular}{|l|} 
R\&D/ \\
REV \% \\
\end{tabular} & \begin{tabular}{|r|} 
Employees \\
end of 2015
\end{tabular} \\
\hline JOHNSON \& JOHNSON & 649.4 & 125.9 & 42.4 & 61.1 & 80.9 & 34 & 49 & 82 & 12 & 127,100 \\
\hline PFIZER & 538.8 & 89.9 & 63.2 & 68.0 & 82.6 & 70 & 76 & 146 & 15 & 97,900 \\
\hline MERCK & 365.2 & 63.1 & 29.7 & 43.1 & 69.3 & 47 & 68 & 115 & 19 & 68,000 \\
\hline ABBOTT LABORATORIES & 285.1 & 40.6 & 13.1 & 20.8 & 26.6 & 32 & 51 & 84 & 9 & 74,000 \\
\hline ELI LILLY & 209.2 & 30.9 & 4.1 & 20.7 & 45.0 & 13 & 67 & 80 & 22 & 41,275 \\
\hline BRISTOL-MYERS SQUIBB & 183.8 & 34.5 & 4.6 & 23.3 & 39.3 & 13 & 67 & 81 & 21 & 25,000 \\
\hline AMGEN & 167.0 & 44.8 & 32.1 & 7.3 & 36.2 & 72 & 16 & 88 & 22 & 17,900 \\
\hline BAXTER INTERNATIONAL & 129.6 & 18.8 & 11.8 & 7.5 & 9.4 & 63 & 40 & 102 & 7 & 50,000 \\
\hline GILEAD SCIENCES & 114.4 & 46.5 & 27.0 & 1.9 & 17.1 & 58 & 4 & 62 & 15 & 8,000 \\
\hline ALLERGAN & 60.7 & 2.0 & 0.5 & 0.2 & 6.2 & 23 & 10 & 33 & 10 & 31,200 \\
\hline BIOGEN IDEC & 57.0 & 14.6 & 14.6 & 0.0 & 13.8 & 100 & 0 & 100 & 24 & 7,350 \\
\hline MYLAN & 56.5 & 3.0 & 2.4 & 0.5 & 5.0 & 79 & 16 & 96 & 9 & 35,000 \\
\hline CELGENE & 44.6 & 8.2 & 13.7 & 0.0 & 15.2 & 166 & 0 & 166 & 34 & 6,971 \\
\hline PERRIGO & 27.0 & 2.2 & 0.3 & 0.3 & 1.0 & 14 & 13 & 27 & 4 & 13,500 \\
\hline ENDO INTERNATIONAL PLC & 21.0 & -2.1 & 1.0 & 0.0 & 1.5 & -49 & 0 & -49 & 7 & 6,406 \\
\hline REGENERON PHARMACEUTICALS & 12.1 & 1.5 & 0.0 & 0.0 & 6.4 & 0 & 0 & 0 & 53 & 4,300 \\
\hline ALEXION PHARMACEUTICALS & 9.6 & 1.7 & 0.7 & 0.0 & 2.3 & 42 & 0 & 42 & 24 & 2,924 \\
\hline VERTEX PHARMACEUTICALS & 6.6 & -4.3 & 0.0 & 0.0 & 6.9 & 0 & 0 & $\mathbf{0}$ & 104 & 1,950 \\
\hline Totals, 18 pharma companies, 2006-2015 & 2,938 & 522 & 261 & 255 & 465 & 50 & 49 & 99 & 16 & 618,776 \\
\hline Totals, 459 S\&P500 companies, 2006-2015 & 89,488 & 7,364 & 3,941 & 2,703 & 1,824 & 54 & 37 & 90 & 2.0 & $24,840,743$ \\
\hline 18 pharma as $\%$ of 459 S\&P $500=3.9 \%$ & $3.3 \%$ & $7.1 \%$ & $6.6 \%$ & $9.4 \%$ & $25.5 \%$ & & & & & $2.5 \%$ \\
\hline
\end{tabular}

$\mathrm{REV}=$ revenues; $\mathrm{NI}=$ Net Income; $\mathrm{BB}=$ stock buybacks (aka repurchases); $\mathrm{DV}=$ cash dividends; $\mathrm{R} \& \mathrm{D}=$ research and development expenditures

Notes: a) The pharmaceutical business of Abbott Laboratories became AbbVie on January 1, 2013. b) In November 2012 , US company Watson Pharmaceuticals acquired the Swiss company Actavis, taking its name. In October 2013, Actavis acquired the Irish company Warner Chilcott and changed the merged company's name to Actavis, plc, headquartered in Ireland. In June 2015 Actavis, plc, domiciled in Ireland, acquired Allergan, and changed the merged company's name to Allergan, Plc. c) In February 2014, Endo acquired the Canadian firm Paladin Labs, established global headquarters in Ireland, and was renamed Endo International, plc.

Source: S\&P Compustat database 
The total of $\$ 261$ billion spent on buybacks alone was equivalent to 56 percent of their combined R\&D expenditures. That $\$ 261$ billion could have been returned to households in the form of lower drug prices without infringing on R\&D spending, while shareholders would still have received ample dividends. Or these funds could have been allocated to the development of drugs for high-priority access areas that are otherwise underfunded and underserved.

In the United States, massive distributions of cash to shareholders are not unique to pharmaceutical companies. From 2006 through 2015, 459 companies in the S\&P 500 Index expended $\$ 3.9$ trillion on buybacks, representing 54 percent of net income, on top of paying $\$ 2.7$ trillion in dividends equaling 37 percent of net income. They held much of the remaining profits abroad, sheltered from US taxation (Rubin 2015; Citizens for Tax Justice 2016). Many of America's largest corporations, Pfizer and Merck among them, routinely distribute more than 100 percent of profits to shareholders, generating the extra cash by reducing reserves, selling off assets, taking on debt, or laying off employees (Lazonick et al. 2015). Over the decade 2006-2015, Johnson \& Johnson, Pfizer, and Merck, the three largest pharma companies, spent an annual average of $\$ 4.2$ billion, $\$ 6.3$ billion, and $\$ 3.0$ billion, respectively, on buybacks, while Amgen, the largest independent biopharma company, spent $\$ 3.2$ billion per year.

The profits that a company retains after distributions to shareholders are the financial foundation for investment in innovation. These retained earnings can fund investment in plant and equipment, research and development, and, of critical importance to innovation, training and retaining employees (Lazonick 2015b). Dividends are the traditional, and legitimate, way for a publicly listed corporation to provide income to shareholders, who receive the dividends for holding shares. In contrast, by creating demand for the company's stock that boosts its price, buybacks reward existing shareholders for selling their shares.

The most prominent sharesellers are those corporate executives, investment bankers, and hedge-fund managers who can access non-public information to time their stock sales to take advantage of buyback activity done as open-market repurchases. ${ }^{1}$ Buybacks also automatically increase earnings per share (EPS) by decreasing the number of shares outstanding. Since EPS is a major metric by which stock-market traders evaluate a company's performance, by increasing EPS, buybacks tend to increase demand for a company's stock, thus creating opportunities for stock-market traders to sell their shares at an enhanced gain, even in the absence of increased corporate revenues or profits (Lazonick 2015a).

\section{Pumping Up Executive Pay}

Why do companies buy back their own shares? In "Profits Without Prosperity: Stock Buybacks Manipulate the Market and Leave Most Americans Worse Off," William Lazonick argues that the only logical explanation is that stock-based compensation gives senior executives personal incentives to do buybacks to boost stock prices (Lazonick 2014b). There are two main types of stock-based pay: stock options, for which the realized gains depend on the difference between the stock price on the date the option to buy the shares is exercised and the date the option was granted; and stock awards, for 
which the realized gains depend on the market price of the stock on the date that the award vests (Hopkins and Lazonick 2016).

By using stock buybacks to boost stock prices and hit EPS targets, executives can augment the gains that they realize from exercising options or the vesting of awards. As shown in Table 2, from 2006 through 2015, the average annual total compensation of the 500 highest-paid US executives (not including billion-dollar-plus outliers) ranged from $\$ 15.9$ million in 2009 (when the stock market was down) to \$33.6 million in 2015, with realized gains from the combination of exercising options and vesting of awards constituting from 60 percent to 83 percent of the average annual total pay (Hopkins and Lazonick 2016). ${ }^{2}$ Stock-based pay incentivizes executives to take actions that increase the company's stock price and rewards them for doing so. Buybacks are a means to these ends.

From 2006 through 2015, four to eight percent of the 500 highest-paid executives at US corporations were Pharma executives. The number of pharma executives found among the top 500 highest paid executives has increased in the most recent years, and as a group their average total compensation soared to levels that exceed by comparison the already sharply increased pay of the top 500 as a whole. As the average total compensation of the drug executives scaled new heights from 2012 through 2015, stock-based pay accounted for 83 to 91 percent of the total, and in 2013-2015 many more pharma executives joined the club of 500 highest-paid executives in the United States.

Table 2. 500 highest-paid executives, US corporations, with proportions of mean total direct compensation from stock options and stock awards, and representation of pharma executives among the top500, 2006-2015

\begin{tabular}{|c|c|c|c|c|c|c|c|c|c|}
\hline & \multicolumn{4}{|c|}{ All US Corporations } & \multicolumn{3}{c|}{ Pharma executives among 500 highest paid } \\
\cline { 2 - 11 } & $\begin{array}{c}\text { TDC, } \\
\text { \$m }\end{array}$ & $\begin{array}{c}\text { So/ } \\
\text { TDC } \%\end{array}$ & $\begin{array}{c}\text { SA/ } \\
\text { TDC } \%\end{array}$ & $\begin{array}{c}\text { (SO+SA)/ } \\
\text { TDC\% }\end{array}$ & $\begin{array}{c}\text { TDC, } \\
\text { \$m }\end{array}$ & $\begin{array}{c}\text { So/ } \\
\text { TDC\% }\end{array}$ & $\begin{array}{c}\text { SA/ } \\
\text { TDC\% }\end{array}$ & $\begin{array}{c}\text { No. of } \\
\text { (SO+SA)/ } \\
\text { TDC\% }\end{array}$ & $\begin{array}{c}\text { pharma } \\
\text { execs }\end{array}$ \\
\hline $\mathbf{2 0 0 6}$ & 25.6 & 56 & 17 & 73 & 24.9 & 46 & 31 & 77 & 25 \\
\hline $\mathbf{2 0 0 7}$ & 30.9 & 57 & 19 & 76 & 23.1 & 61 & 14 & 75 & 18 \\
\hline $\mathbf{2 0 0 8}$ & 20.7 & 48 & 23 & 71 & 22.5 & 63 & 13 & 76 & 22 \\
\hline $\mathbf{2 0 0 9}$ & 15.9 & 37 & 23 & 60 & 21.5 & 39 & 19 & 58 & 31 \\
\hline $\mathbf{2 0 1 0}$ & 19.6 & 38 & 27 & 65 & 20.5 & 39 & 33 & 72 & 27 \\
\hline $\mathbf{2 0 1 1}$ & 21.0 & 39 & 30 & 70 & 19.6 & 52 & 16 & 68 & 24 \\
\hline $\mathbf{2 0 1 2}$ & 32.0 & 41 & 38 & 79 & 35.0 & 58 & 25 & 83 & 24 \\
\hline $\mathbf{2 0 1 3}$ & 27.2 & 46 & 34 & 79 & 34.1 & 67 & 24 & 91 & 37 \\
\hline $\mathbf{2 0 1 4}$ & 31.7 & 45 & 34 & 79 & 43.3 & 69 & 19 & 88 & 42 \\
\hline $\mathbf{2 0 1 5}$ & 33.6 & 47 & 36 & 83 & 44.3 & 55 & 33 & 87 & 37 \\
\hline
\end{tabular}

$\mathrm{TDC}=$ total direct compensation; $\mathrm{SO}=$ realized gains from exercising stock options; $\mathrm{SA}=$ realized gains from vesting of stock awards

Top 500 Sorted by ExecuComp TOTAL_ALT2: salary, bonus, nonequity, change in the value of pension, realized gains from stock options and stock awards

Pharmaceutical executives from companies with NAICS 325411, 325412, 325413, 325414. Note that some of these executives are at pharmaceutical companies that are not among the 18 pharmaceutical companies in the S\&P 500 Index, identified in Table 1.

Source: S\&P ExecuComp database (data retrieved July 31, 2017)

Table 3 shows that, among the 18 pharma companies in the S\&P 500 Index, a younger set of biopharma companies launched in the late 1980s and early 1990s account for the explosion in pharma executive pay. Table 4, which selects from all pharma executives in 
the S\&P ExecuComp database (and not just from those companies in the S\&P 500 Index in January 2016), identifies the six highest-paid pharma executives for each year from 2006 through 2015. Note the prominence, especially in 2012-2015, of executives from three of the biopharma companies in Table 3: Gilead Sciences (15 of the 60 cells), Celgene (7), and Regeneron (6). Also note the extent to which their pay is stock based. Gilead Sciences CEO John C. Martin appears on this top 6 list in all ten years, four times in first place, three times in second, twice in third, and once (2006) in sixth.

Table 3. Biopharma and the explosion of executive pay, 2012, 2013, 2014, and, 2015

\begin{tabular}{|c|c|c|c|c|c|c|c|c|}
\hline & \multicolumn{8}{|c|}{ Number of executives in top 500} \\
\hline & \multicolumn{2}{|c|}{2012} & \multicolumn{2}{|c|}{2013} & \multicolumn{2}{|c|}{2014} & \multicolumn{2}{|c|}{2015} \\
\hline Company (year founded) & $\begin{array}{l}\text { No. of } \\
\text { exec- } \\
\text { utives }\end{array}$ & $\begin{array}{c}\text { Mean } \\
\text { TDC, } \\
\text { \$m } \\
\end{array}$ & $\begin{array}{l}\text { No. of } \\
\text { exec- } \\
\text { utives }\end{array}$ & $\begin{array}{c}\text { Mean } \\
\text { TDC, } \\
\$ \mathrm{~m} \\
\end{array}$ & $\begin{array}{l}\text { No. of } \\
\text { exec- } \\
\text { utives }\end{array}$ & $\begin{array}{c}\text { Mean } \\
\text { TDC, } \\
\text { \$m } \\
\end{array}$ & $\begin{array}{l}\begin{array}{l}\text { No. of } \\
\text { exec- } \\
\text { utives }\end{array} \\
\end{array}$ & $\begin{array}{c}\text { Mean } \\
\text { TDC, } \\
\text { \$m } \\
\end{array}$ \\
\hline GILEAD SCIENCES (1987) & 3 & 42.6 & 4 & 74.7 & 5 & 82.4 & 5 & 97.3 \\
\hline REGENERON (1988) & 5 & 51.3 & 4 & 53.0 & 4 & 56.6 & 3 & 66.5 \\
\hline ALEXION (1992) & 2 & 32.0 & 4 & 20.8 & 2 & 111.3 & 1 & 51.6 \\
\hline CELGENE (1986) & 0 & & 3 & 27.5 & 1 & 96.3 & 3 & 16.8 \\
\hline VERTEX (1989) & 0 & & 1 & 36.6 & 1 & 28.9 & 0 & \\
\hline Executives, 5 pharma & 10 & 42.0 & 16 & 42.5 & 13 & 75.1 & 12 & 58.1 \\
\hline Executives, 18 pharma & 20 & 37.5 & 33 & 36.1 & 31 & 46.6 & 27 & 46.9 \\
\hline All executives in 500 & 500 & 32.0 & 500 & 27.2 & 500 & 31.7 & 500 & 33.6 \\
\hline
\end{tabular}

Source: S\&P ExecuComp database (data retrieved July 31, 2017)

Table 4. Six highest-compensated pharma executives, 2006-2015, with total compensation in millions of dollars (stock-based pay as percent of total compensation)

\begin{tabular}{|c|c|c|c|c|c|c|}
\hline & \#1 & \#2 & $\# \mathbf{3}$ & $\# 4$ & $\# 5$ & $\# 6$ \\
\hline & John W. Jackson & Kenneth E. Goodman & Sol J. Barer & Howard Solomon & Robert A. Essner & John C. Martin \\
\hline \multirow[t]{3}{*}{2006} & CELGENE & FOREST LABS & CELGENE & FOREST LABS & WYETH & GILEAD SCIENCES \\
\hline & $\$ 84.5 \mathrm{~m}[96 \%)$ & $\$ 78.2 \mathrm{~m}(99 \%)$ & $\$ 46.1 \mathrm{~m}[94 \%)$ & $\$ 40.9 \mathrm{~m}(96 \%)$ & $\$ 34.1 \mathrm{~m}(73 \%)$ & $\$ 32.5 \mathrm{~m}(92 \%)$ \\
\hline & Miles D. White & David E. L. Pyott & John C. Martin & Richard A. Gonzalez & Henri A. Termeer & Norbert W. Bischofberger \\
\hline \multirow[t]{3}{*}{2007} & ABBOTT & ALLERGAN & GILEAD SCIENCES & ABBOTT & GENZYME & GILEAD SCIENCES \\
\hline & $\$ 47.8 \mathrm{~m}(79 \%)$ & $\$ 46.0 \mathrm{~m}(93 \%)$ & $\$ 35.6 \mathrm{~m}[93 \%]$ & $\$ 30.7 \mathrm{~m}(88 \%)$ & $\$ 24.7 \mathrm{~m}(85 \%)$ & $\$ 24.2 \mathrm{~m}(95 \%)$ \\
\hline & Robert J. Hugin & Sol J. Barer & John C. Martin & Miles D. White & William C. Weldon & James C. Mullen \\
\hline \multirow[t]{3}{*}{2008} & CELGENE & CELGENE & GILEAD SCIENCES & ABBOTT & $J \& J$ & BIOGEN \\
\hline & $\$ 74.6 \mathrm{~m}(97 \%)$ & $\$ 59.3 \mathrm{~m}(94 \%)$ & $\$ 33.1 \mathrm{~m}[91 \%)$ & $\$ 30.3 \mathrm{~m}(67 \%)$ & $\$ 25.6 \mathrm{~m}[11 \%)$ & $\$ 24.9 \mathrm{~m}(84 \%)$ \\
\hline & Fred Hassan & John C. Martin & Robert J. Bertolini & Carrie Smith Cox & Thomas Paul Koestler & Sol J. Barer \\
\hline \multirow[t]{3}{*}{2009} & MERCK & GILEAD SCIENCES & MERCK & MERCK & MERCK & CELGENE \\
\hline & $\$ 91.3 \mathrm{~m}(61 \%)$ & $\$ 60.4 \mathrm{~m}[94 \%)$ & $\$ 58.5 \mathrm{~m}(17 \%)$ & $\$ 46.2 \mathrm{~m}[40 \%)$ & $\$ 38.9 \mathrm{~m}(46 \%)$ & $\$ 31.4 \mathrm{~m}(87 \%)$ \\
\hline & John C. Martin & David E. L. Pyott & Martine A. Rothblatt & William C. Weldon & James C. Mullen & Christopher B. Begley \\
\hline \multirow[t]{3}{*}{2010} & GILEAD SCIENCES & ALLERGAN & UNITED THERAPEUTICS & J\&J & BIOGEN & HOSPIRA \\
\hline & $\$ 42.7 \mathrm{~m}[91 \%]$ & $\$ 35.3 \mathrm{~m}(87 \%)$ & \begin{tabular}{|l} 
\\
$\$ 31.6 \mathrm{~m}[89 \%)$ \\
\end{tabular} & $\$ 25.4 \mathrm{~m}(17 \%)$ & $\$ 24.6 \mathrm{~m}[93 \%)$ & $\$ 23.6 \mathrm{~m}[88 \%)$ \\
\hline & John C. Martin & David E. L. Pyott & William C. Weldon & Jonah Shacknai & Miles D. White & Robert L. Parkinson, Jr. \\
\hline \multirow[t]{3}{*}{2011} & GILEAD SCIENCES & ALLERGAN & J\&J & MEDICIS & ABBOTT & BAXTER \\
\hline & $\$ 43.2 \mathrm{~m}[90 \%)$ & $\$ 35.8 \mathrm{~m}[86 \%)$ & $\$ 27.8 \mathrm{~m}(28 \%)$ & $\$ 25.3 \mathrm{~m}(38 \%)$ & $\$ 22.6 \mathrm{~m}(45 \%)$ & $\$ 22.6 \mathrm{~m}(75 \%)$ \\
\hline & George D. Yancopoulos & John C. Martin & Robert J. Coury & Leonard S. Schleifer & Leonard Bell & David E. L. Pyott \\
\hline \multirow[t]{3}{*}{2012} & REGENERON & GILEAD SCIENCES & MYLAN & REGENERON & ALEXION & ALLERGAN \\
\hline & $\$ 129.8 \mathrm{~m}(98 \%)$ & $\$ 85.5 \mathrm{~m}[94 \%)$ & $\$ 68.6 \mathrm{~m}(69 \%)$ & $\$ 52.5 \mathrm{~m}(93 \%)$ & $\$ 41.6 \mathrm{~m}[91 \%)$ & $\$ 41.4 \mathrm{~m}(88 \%)$ \\
\hline & John C. Martin & Paul M. Bisaro & John F. Milligan & George D. Yancopoulos & Leonard S. Schleifer & Robert J. Hugin \\
\hline \multirow[t]{3}{*}{2013} & GILEAD SCIENCES & ALLERGAN & GILEAD SCIENCES & REGENERON & REGENERON & CELGENE \\
\hline & $\$ 168.9 \mathrm{~m}(97 \%)$ & $\$ 113.2 \mathrm{~m}(95 \%)$ & $\$ 79.7 \mathrm{~m}[97 \%)$ & $\$ 74.5 \mathrm{~m}(96 \%)$ & $\$ 73.5 \mathrm{~m}(96 \%)$ & $\$ 46.4 \mathrm{~m}(81 \%)$ \\
\hline & Leonard Bell & John C. Martin & Leonard S. Schleifer & Robert J. Hugin & John F. Milligan & Rajat Rai \\
\hline \multirow[t]{3}{*}{2014} & ALEXION & GILEAD SCIENCES & REGENERON & CELGENE & GILEAD SCIENCES & AKORN \\
\hline & $\$ 195.8 \mathrm{~m}(98 \%)$ & $\$ 192.8 \mathrm{~m}(97 \%)$ & $\$ 101.8 \mathrm{~m}(97 \%)$ & $\$ 96.3 \mathrm{~m}(89 \%)$ & $\$ 89.5 \mathrm{~m}[97 \%)$ & $\$ 75.8 \mathrm{~m}[97 \%)$ \\
\hline & John C. Martin & George D. Yancopoulos & John F. Milligan & Martine A. Rothblatt & Norbert W. Bischofberger & Rajat Rai \\
\hline \multirow[t]{2}{*}{2015} & GILEAD SCIENCES & REGENERON & GILEAD SCIENCES & UNITED THERAPEUTICS & GILEAD SCIENCES & AKORN \\
\hline & $\$ 232.0 \mathrm{~m}(98 \%)$ & $\$ 104.5 \mathrm{~m}(97 \%)$ & $\$ 103.4 \mathrm{~m}(97 \%)$ & $\$ 96.7 \mathrm{~m}(98 \%)$ & $\$ 95.5 \mathrm{~m}(98 \%)$ & $\$ 67.3 \mathrm{~m}[97 \%)$ \\
\hline
\end{tabular}

Source: S\&P ExecuComp database (data retrieved July 31, 2017) 


\section{Gilead's Greed is US Pharma's Creed}

Gilead Sciences exemplifies the financialized price-gouging drug companies that dominate the US pharmaceutical industry (see Roy and King 2016; Mazzucato 2016). In November 2011, Gilead Sciences won a bidding war, paying $\$ 11.2$ billion to acquire Pharmasset, a young biopharma company based in Atlanta, Georgia, which had developed sofosbuvir, a nucleotide analog that acts to inhibit the replication of the Hepatitis-C virus (HCV). In December 2013, Gilead secured US Food and Drug Administration (FDA) approval of sofosbuvir, which it has sold under the brand name Sovaldi. In October 2014, the company also gained FDA approval of the fixed-dose combination of ledipasvir and sofosbuvir, sold as Harvoni. Sovaldi is taken with other drugs, whereas Harvoni is taken on its own. Both are highly effective in curing certain genotypes of $\mathrm{HCV}^{3}$ In June 2016, Gilead received approval of the fixed-dose combination of velpatasvir and sofosbuvir, marketed as Epclusa, which is effective for all six genotypes of HCV. ${ }^{4}$ With the introduction of these drugs, Gilead's US price tags for 12week treatments were $\$ 84,000$ for Sovaldi, $\$ 94,500$ for Harvoni, and $\$ 74,760$ for Epclusa.

An 18-month Congressional inquiry by US Senators Ron Wyden (D-OR) and Charles Grassley (R-IA) probed the rationale for Gilead's Sovaldi pricing strategy, concluding, in a report issued on December 1, 2015, that "a key consideration in Gilead's decisionmaking process to determine the ultimate price of Sovaldi was setting the price such that it would not only maximize revenue, but also prepare the market for Harvoni and its even higher price" (The Staffs of Senators). But the Wyden-Grassley report made no attempt to probe the influence and impact of Gilead's mode of executive compensation on its strategy to charge high drug prices for the sake on an exploding stock price. In our view, the objective of Gilead's executives in setting high prices was not to maximize revenue but rather to "maximize shareholder value" so that soaring stock prices would translate into enormous compensation packages. ${ }^{5}$

In an interview in December 2013, Gregg H. Alton, Gilead vice-president of corporate and medical affairs, defended the price of Sovaldi by saying: "Really you need to look at the big picture. Those who are bold and go out and innovate like this and take that risk, there needs to be more of a reward on that. Otherwise it would be very difficult for people to make that investment" (The Staffs of Senators 2015, p. 108). But whose risks are being rewarded? Over its entire corporate history, Gilead has secured a total of $\$ 376$ million from public share issues, all between 1991, when it did its IPO, and 1996. Especially since Gilead only began paying dividends in 2015, it is probable that virtually all of those shareholders have long since sold their shares to secure capital gains. Current shareholders are just stock-market traders who have bought outstanding shares. So why are Gilead's senior executives so intent on "creating value" for shareholders who have contributed nothing to the development of Gilead's products? As indicated in Table 4 above and as we elaborate below, Gilead's senior executive pay packages provide the answer.

The greed of Gilead's top executives, sanctioned by MSV ideology, is preventing millions of people with HCV in the United States and abroad from accessing Sovaldi, Harvoni and Epclusa at affordable prices. ${ }^{6}$ We need a business model that shares the 
gains from innovative medicines with households as taxpayers who fund the government agencies that provide intellectual and financial support to the drug companies, households as workers whose skills and efforts have developed the drugs, and households as consumers who have illnesses waiting to be cured or relieved. In contrast, the MSV business model concentrates the gains from innovative medicines in the hands of senior corporate executives and activist shareholders who pad their paychecks by having the company do billions of dollars of stock buybacks to manipulate the company's stock price (see Lazonick and Shin 2017).

Founded in 1987 with its initial public offering on NASDAQ in 1990, Gilead sustained combined net losses of $\$ 210$ million from 1990 through 2006, including a loss of $\$ 1.2$ billion in 2006 after booking combined profits of $\$ 1.3$ billion in 2004 and 2005. Tables 5a and 5b show Gilead's sales, profits, R\&D spending, and distributions to shareholders from 2007 through 2016, a decade marked by sustained profitability that soared in 2014 and 2015 as a result of sales of Sovaldi and Harvoni.

Table 5a. Gilead Sciences, operating data, dividends, and buybacks, 2007-2016

\begin{tabular}{|c|c|c|c|c|c|c|}
\hline $\begin{array}{l}\text { Fiscal } \\
\text { year }\end{array}$ & $\begin{array}{l}\text { REV } \\
\$ \mathrm{~m} \\
\end{array}$ & $\begin{array}{l}\mathrm{NI} \\
\$ \mathrm{~m}\end{array}$ & $\begin{array}{l}\text { BB } \\
\$ \mathrm{~m}\end{array}$ & $\begin{array}{l}\text { DV } \\
\text { \$m }\end{array}$ & $\begin{array}{c}\text { R\&D } \\
\$ \mathrm{~m}\end{array}$ & EMP \\
\hline 2007 & 4,230 & 1,615 & 488 & 0 & 591 & 2,979 \\
\hline 2008 & 5,336 & 2,011 & 1,970 & 0 & 733 & 3,441 \\
\hline 2009 & 7,011 & 2,636 & 998 & 0 & 940 & 3,852 \\
\hline 2010 & 7,949 & 2,901 & 4,023 & 0 & 1,073 & 4,000 \\
\hline 2011 & 8,385 & 2,804 & 2,383 & 0 & 1,229 & 4,500 \\
\hline 2012 & 9,703 & 2,592 & 667 & 0 & 1,760 & 5,000 \\
\hline 2013 & 11,202 & 3,075 & 582 & 0 & 2,120 & 6,100 \\
\hline 2014 & 24,890 & 12,101 & 5,349 & 0 & 2,854 & 7,000 \\
\hline 2015 & 32,639 & 18,108 & 10,002 & 1,874 & 3,014 & 8,000 \\
\hline 2016 & 30,390 & 13,501 & 11,001 & 2,455 & 5,098 & 9,000 \\
\hline $\begin{array}{l}2007- \\
2016\end{array}$ & 141,735 & 61,343 & 37,463 & 4,329 & 19,411 & \\
\hline
\end{tabular}

$\mathrm{REV}=$ revenues; $\mathrm{NI}=$ net income; $\mathrm{BB}=$ stock buybacks; $\mathrm{DV}=$ cash dividends; $\mathrm{R} \& \mathrm{D}=$ research and development expenditures; $\mathrm{EMP}=$ employees

Source: S\&P Compustat database

Table 5b. Gilead Sciences, operating and payout ratios, 2007-2016

\begin{tabular}{|l|r|r|r|r|r|r|r|}
\hline $\begin{array}{l}\text { Fiscal } \\
\text { year }\end{array}$ & $\begin{array}{c}\text { NI/REV } \\
\text { \% }\end{array}$ & \multicolumn{1}{c|}{$\begin{array}{c}\text { BB/NI } \\
\text { \% }\end{array}$} & \multicolumn{1}{c|}{$\begin{array}{c}\text { DV/NI } \\
\text { \% }\end{array}$} & $\begin{array}{c}\text { (BB+DV } / \\
\text { NI\% }\end{array}$ & $\begin{array}{c}\text { BB/ } \\
\text { R\&D }\end{array}$ & $\begin{array}{c}\text { R\&D/ } \\
\text { REV } \\
\%\end{array}$ & $\begin{array}{c}\text { REV/ } \\
\text { EMP } \\
\text { \$m }\end{array}$ \\
\hline $\mathbf{2 0 0 7}$ & 38.2 & 30.2 & 0.0 & 30.2 & 0.8 & 14.0 & 1.4 \\
\hline $\mathbf{2 0 0 8}$ & 37.7 & 97.9 & 0.0 & 97.9 & 2.7 & 13.7 & 1.6 \\
\hline $\mathbf{2 0 0 9}$ & 37.6 & 37.9 & 0.0 & 37.9 & 1.1 & 13.4 & 1.8 \\
\hline $\mathbf{2 0 1 0}$ & 36.5 & 138.7 & 0.0 & 138.7 & 3.7 & 13.5 & 2.0 \\
\hline $\mathbf{2 0 1 1}$ & 33.4 & 85.0 & 0.0 & 85.0 & 1.9 & 14.7 & 1.9 \\
\hline $\mathbf{2 0 1 2}$ & 26.7 & 25.7 & 0.0 & 25.7 & 0.4 & 18.1 & 1.9 \\
\hline $\mathbf{2 0 1 3}$ & 27.4 & 18.9 & 0.0 & 18.9 & 0.3 & 18.9 & 1.8 \\
\hline $\mathbf{2 0 1 4}$ & 48.6 & 44.2 & 0.0 & 44.2 & 1.9 & 11.5 & 3.6 \\
\hline $\mathbf{2 0 1 5}$ & 55.5 & 55.2 & 10.3 & 65.6 & 3.3 & 9.2 & 4.1 \\
\hline $\mathbf{2 0 1 6}$ & 44.4 & 81.5 & 18.2 & 99.7 & 2.2 & 16.8 & 3.4 \\
\hline $\mathbf{2 0 0 7}$ & & & & & & & \\
$\mathbf{2 0 1 6}$ & $\mathbf{4 3 . 3}$ & $\mathbf{6 1 . 1}$ & $\mathbf{7 . 1}$ & $\mathbf{6 8 . 1}$ & $\mathbf{1 . 9}$ & $\mathbf{1 3 . 7}$ & \\
\hline
\end{tabular}

Notes and source are the same as Table 5a. 
Prior to 2014 Gilead had two blockbuster drugs, with Truvada, launched in 2004, reaching \$3.6 billion in sales in 2016, and Atripla, launched in 2006, generating a high of $\$ 3.6$ billion in 2013. In their first full years on the market, Sovaldi had sales of $\$ 10.3$ billion in 2014 and Harvoni $\$ 13.9$ billion in 2015. As a result of Sovaldi and Harvoni sales, Gilead's revenues and profits exploded in these two years (see Table 5a). Together, increased sales of these two drugs accounted for 90 percent of Gilead's rise in total revenues from $\$ 11.2$ billion in 2013 to $\$ 24.9$ billion in 2014 , and 88 percent of the increase from $\$ 24.9$ billion in 2014 to $\$ 32.6$ billion in 2015 .

Gilead's price gouging of Sovaldi and Harvoni users permitted the extra-high profit margins (NI/REV\% in Table 5b) that the company achieved in 2014 through 2016. Gilead used the profits from its price gouging on the drug market to do stock buybacks to manipulate stock prices. Pre-Sovaldi/Harvoni, Gilead was already doing substantial buybacks, but, as can be seen in Table 5a, these reached massive levels in 2014, 2015, and 2016, with a three-year total of $\$ 26.3$ billion. As we have stressed more generally, the only purpose of these stock buybacks is to manipulate the company's stock price, enabling senior executives to inflate their stock-based pay. Gilead increased its R\&D expenditures substantially in 2016, in line with its skyrocketing revenues, but, even then, its buybacks were more than double its R\&D spending. When combined with dividends, Gilead's distributions to shareholders absorbed virtually all of its $\$ 13.5$ billion in profits in 2016.

Gilead's stock price increased by about 80 percent in the year following its November 2011 acquisition of Pharmasset and then, over the following year, rose another 100 percent by December 2013, when sofosbuvir won FDA approval (see Figure 1). The stock price then increased another 60 percent by June/July 2015, after which it declined to about the level that it had reached at the time of the launch of Sovaldi at the end of 2013. Gilead's stock-price boom greatly enriched its top executives.

How much did Gilead's booming stock price increase the take-home pay of the company's senior executives? In a hard-hitting article entitled "Gilead's greed that kills," economist Jeffrey Sachs (2015) makes the case that the pricing of Sovaldi and Harvoni handed Gilead CEO Martin "the spoils of untrammeled greed":

Gilead Sciences is an American pharmaceutical company driven by unquenchable greed. The company is causing hundreds of thousands of Americans with Hepatitis $C$ to suffer unnecessarily and many of them to die as the result of its monopolistic practices, while public health programs face bankruptcy. Gilead CEO John C. Martin took home a reported \$19 million last year in compensation - the spoils of untrammeled greed.

A glance at Table 4 above reveals, however, that Martin's actual compensation in 2014 was not $\$ 19$ million, but more than ten times that amount: $\$ 192.8$ million-with 97 percent coming from gains from stock-based pay. What accounts for this vast discrepancy? As Matt Hopkins and William Lazonick (2016) explain, the "reported \$19 million" that Sachs cites is an "estimated fair value" (EFV) accounting measure of executive compensation that vastly understates CEO Martin's "money-in-the-bank" compensation, which includes his actual realized gains (ARG) from the exercise of stock options and the vesting of stock awards. 
Figure 1. Gilead Sciences (GILD: NASDAQ) stock price (monthly adjusted close), January 1992-June 2017

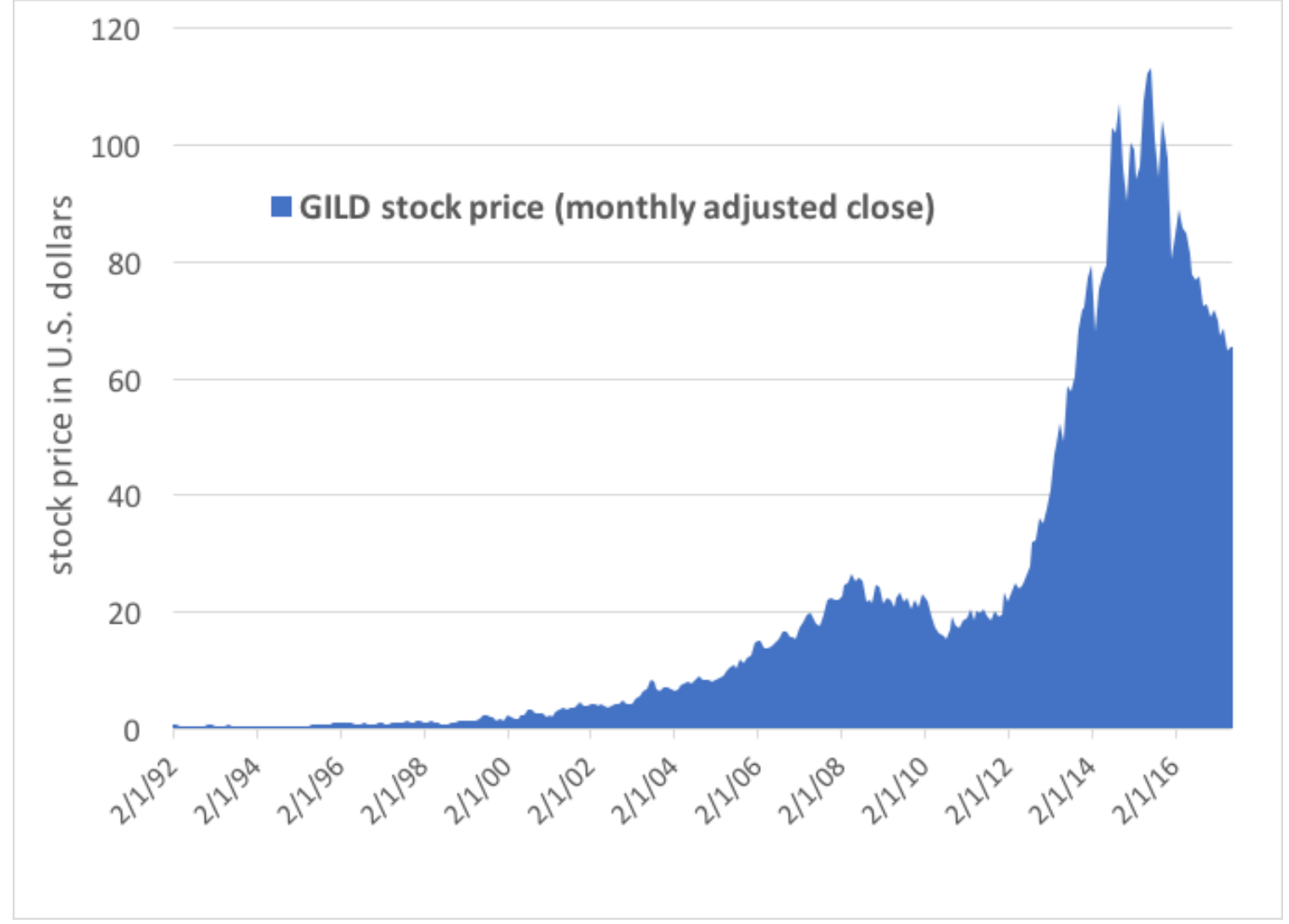

Source: Yahoo Finance, monthly data, adjusted close.

For the decade 2006-2015, the EFV measure of Martin's total compensation added up to \$151.9 million but his total ARG compensation, which he took home and reported to the US Internal Revenue Service as taxable remuneration, was \$926.5 million, of which 96 percent was stock based. Figure 2 compares the total ARG remuneration of John C. Martin over his 20 years as CEO of Gilead with the figures predicted using the EFV formulae. His EFV pay over the two decades was $\$ 208.6$ million but his actual pay was almost five time that, totaling $\$ 1,000.9$ million.

In 2014, the actual pay packages of the other four Gilead executives named on the company's proxy statement were: John F. Milligan, $\$ 89.5$ million (97 percent stock based); Gregg H. Alton, \$52.6 million (97 percent); Norbert W. Bischofberger, \$50.7 million (96 percent); and Robin L. Washington, \$26.6 million (93 percent). In 2015, the compensation of Martin was \$232.0 million (98 percent); Milligan, \$103.4 million (97 percent); Bischofberger, \$95.5 million (98 percent); Alton, \$33.6 million (94 percent); and Washington, $\$ 22.0$ million (91 percent). In 2016, the compensation of Martin (by then retired as CEO, but continuing as executive chairman) was $\$ 98.4$ million (96 percent); new CEO Milligan, \$57.8 million (93 percent); Alton, $\$ 8.5$ million (78 percent); Bischofberger, \$6.2 million (68 percent); Kevin B. Young, \$5.9 million (69 percent); and Washington, $\$ 5.1$ million (67 percent). 
Figure 2. Remuneration of John C. Martin as CEO of Gilead Sciences, 1996-2015, by total estimated fair value (EFV) pay and total actual realized gains (ARG) pay

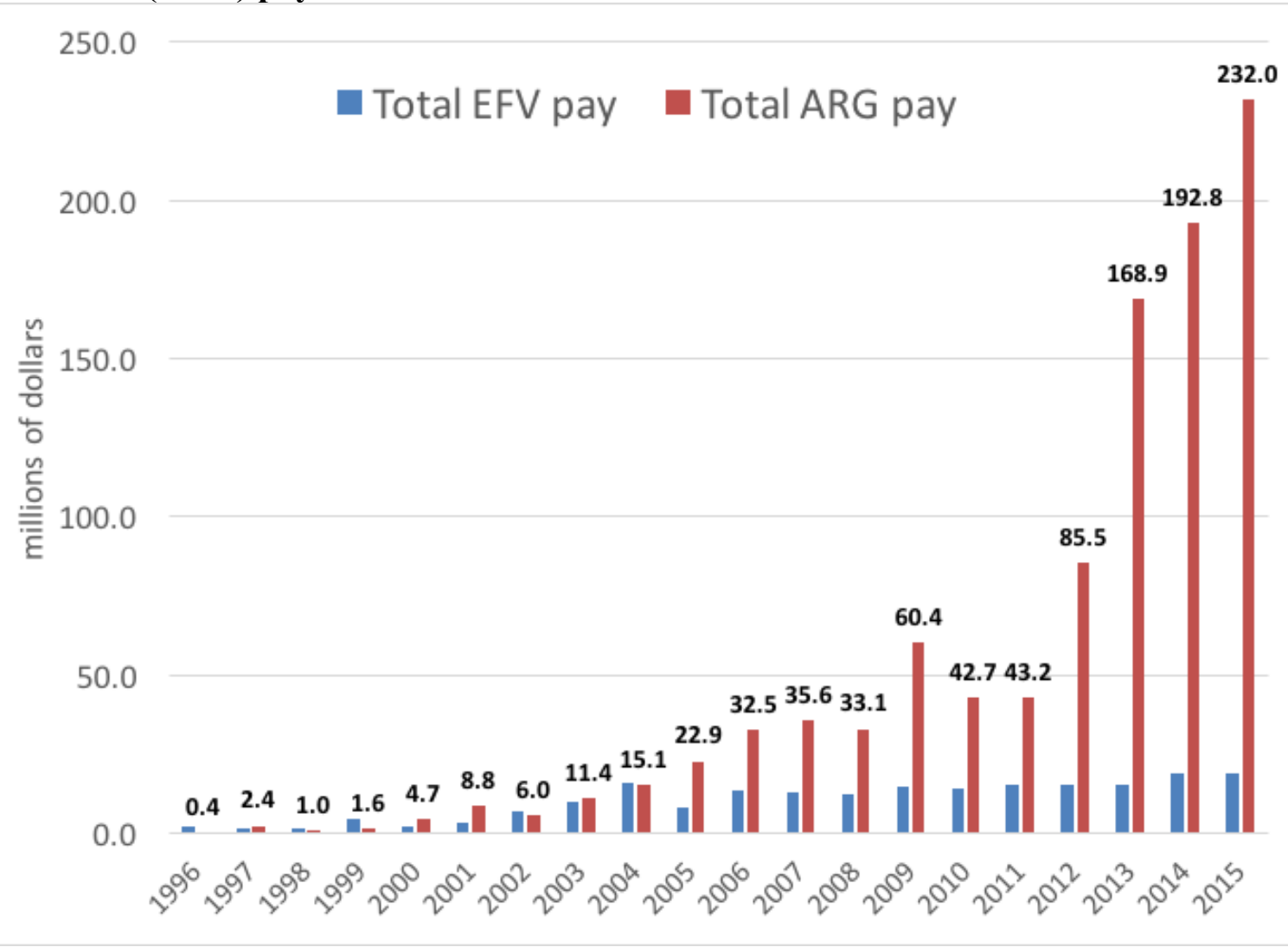

Source: S\&P ExecuComp database

Our analysis of the relation between innovation and financialization at Gilead supports the hypothesis that these enormous executive pay packages reward stock-price speculation and manipulation rather than the company's success at innovation. ${ }^{7}$ Gilead has built its business by acquiring companies-NexStar (for $\$ 550$ million in 1999), Triangle Pharmaceuticals (for \$464 million in 2003), Myogen (for \$2.5 billion in 2006), CV Therapeutics (for $\$ 1.4$ billion in 2011), and Pharmasset (for $\$ 11.2$ billion in 2011) that discovered and largely developed the drugs that have generated virtually all of Gilead's revenues over its 30-year history. The only compounds that have been developed by Gilead are ledipasvir (in Harvoni), velpatasvir (in Epclusa), and tenofovir alafenamide (in Genova, introduced in 2015, and Odefsey and Descovy, introduced in 2016), all of which have been combined with drugs developed elsewhere but brought to market by Gilead.

As with most US pharmaceutical medicines, the history of the design and development of the drugs that Gilead sells has built on seminal research performed, often over decades, with government funding by the US National Institutes of Health (NIH). Indeed, as shown in Figure 3, the NIH's 2016 budget of $\$ 32.3$ billion is, in real terms, triple NIH's annual spending in the mid-1980s and double that in the mid-1990s (National Institutes of Health 2016). 
Figure 3. National Institutes of Health funding of life sciences research, 1938-2016 in 2016 dollars

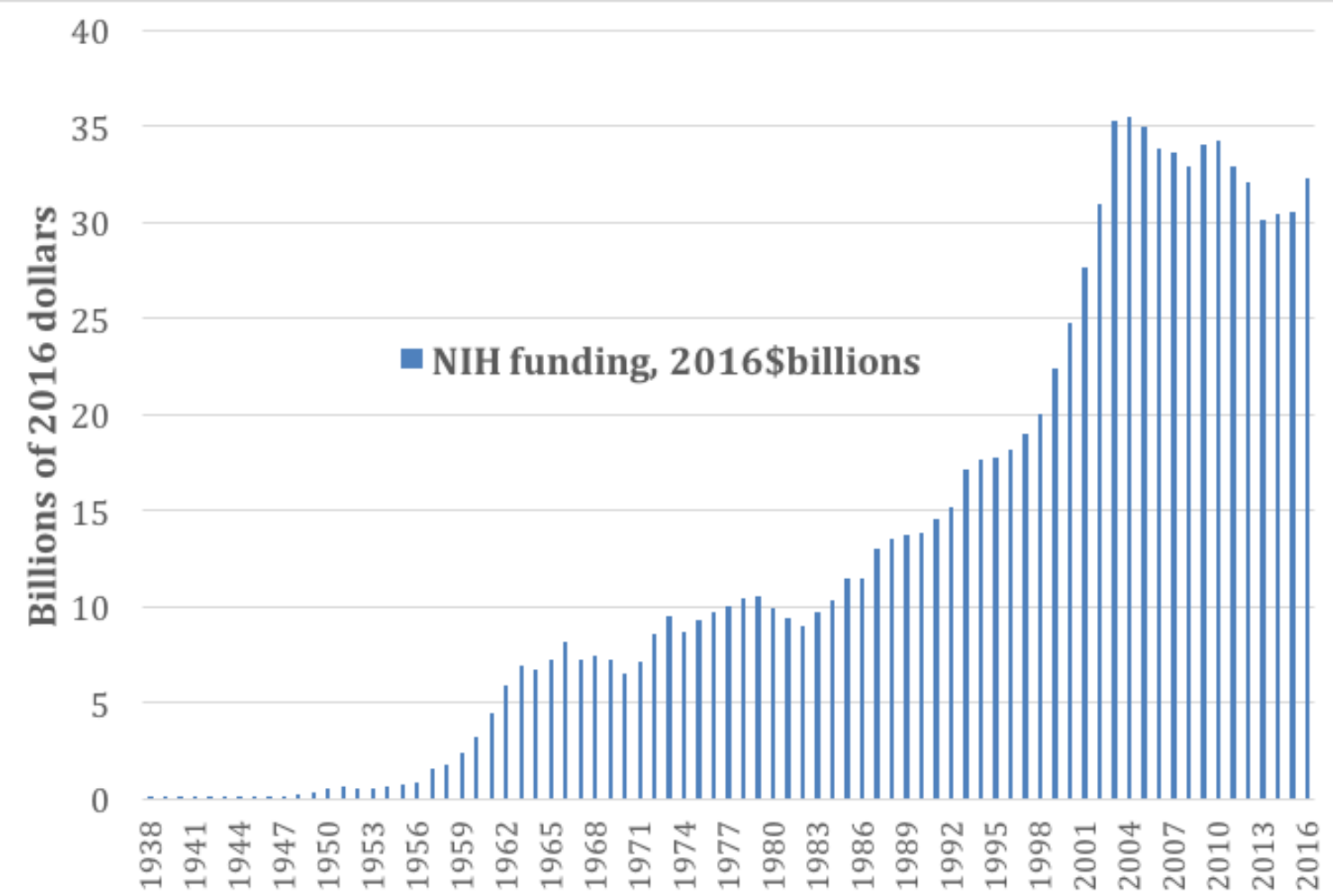

Source: National Institutes of Health Budget at Budget, at https://www.nih.gov/about-nih/what-we-do/budget

For decades before companies like Celgene, Gilead, Cephalon, Regeneron, Vertex, and Alexion were founded, NIH funding had been critical to drug innovation. At a meeting with French President François Mitterrand in Silicon Valley in 1984, documented in a Washington Post report (Henderson and Schrage 1984), venture capitalist Thomas Perkins, whose firm brought Genentech from startup in 1976 to IPO in 1980, "extolled the virtues of the risk-taking investors who finance the entrepreneurs." The Post article goes on to say:

Perkins was cut off by Stanford University Professor Paul Berg, who won a Nobel Prize for work in genetic engineering. "Where were you guys in the '50s and ' $60 \mathrm{~s}$ when all the funding had to be done in the basic science? Most of the discoveries that fueled [the industry] were created back then....I cannot imagine that if there had not been an NIH funding research, that there would have been a biotechnology industry," Berg said. ${ }^{8}$

In the decade after the discovery of recombinant DNA in 1973, venture capitalists (who had emerged in the context of the microelectronics revolution) in combination with "star" university scientists (including Nobel Prize winners) launched biopharma startups, a number of which - most notably Genentech, Amgen, Biogen, and Genzyme - became highly visible companies. Beginning in 1980 these four companies and many other biopharma startups went public on the NASDAQ stock exchange. Many observers have attributed the success of these early biopharma companies in developing "blockbuster" 
drugs to the plucking of "the low-hanging fruit" of decades of NIH-funded research (Nightingale and Martin 2004; Munos 2006; Scannell et al. 2012). Aiding these companies in reaching for the fruit and ripening it into commercial drugs were regulatory and legal changes in the early 1980s, including the Bayh-Dole Act of 1980 that facilitated the commercialization of federally funded research; the 1980 Supreme Court ruling in Diamond v. Chakrabarty that permitted the patenting of a gene; the Stevenson-Wydler Technology Innovation Act of 1980 that required federal research labs to engage in technology transfer activities; and the Orphan Drug Act of 1983 that provided government support and intellectual property protection to companies for the development of commercial drugs for rare and genetic diseases (Wright 1986; Lazonick and Tulum 2011).

As these early commercial successes, originating with NIH grants and further supported under the Orphan Drug Act, reinforced the willingness of venture capitalists to invest in biopharma startups, it became increasingly possible to list a young biomedical company on NASDAQ even though it was just a research entity seeking to discover its first product. William Lazonick, Mustafa Erdem Sakinç, and Öner Tulum have called such a publicly listed company a product-less IPO, or PLIPO (Lazonick and Sakinç 2010; Lazonick and Tulum 2011; Sakinç and Tulum 2012). As of December 2015, the United States had 2,772 biotech companies of which 436 companies (with 131,690 employees) were publicly listed (Ernst \& Young 2016, p. 18). PLIPOs can raise funds through primary and secondary stock issues because of the willingness of stock-market traders, including hedge fund managers, to speculate on publicly traded biomedical shares, buying and selling them on "news" such as that generated by clinical trials, but without any concern about whether a commercial drug is ever actually produced.

This funding model is very disruptive of the collective and cumulative learning that is needed for successful drug development. The stock-market speculation that creates opportunities for PLIPOs to issue public equity ebbs and flows, and at times even comes to a complete stop, as was the case in 2008-2010 when, given the financial crisis, there were virtually no biotech IPOs. In the process, employment in these companies is also volatile, and the learning that occurs tends to be neither collective nor cumulative.

Yet, as Gary Pisano (2006) has emphasized, in this "science business", product development times can extend for a decade or longer, largely because of the three phases of clinical trials before the US Food and Drug Administration will approve a drug as safe to use. If there is any industry in which collective and cumulative learning by highly educated people is essential, it is in the biomedical industry. The industry's business model caters, however, to those who seek to gain from the volatile stock market, and publicly listed firms in the industry have received much of their funding from speculative traders who represent the antithesis of the "patient capitalists" that drug development requires.

To some extent this problem can be overcome by the participation of big pharma in funding the growth of biotech startups until a commercial product emerges, and in the 40year history of the biopharmaceutical industry such big pharma funding has often been the case. The potential for such funding need not be limited to US big pharma companies. Many of the large European and Japanese pharmaceutical companies have funded US PLIPOs, either through outright acquisition or through large research contracts that 
include equity stakes and rights to sell the drug in certain parts of the world if it is ever produced (Andersson et al. 2010; Umemura 2010; Montalban and Sakinç 2013; Tulum 2017). Likewise, US big pharma has also at times provided patient capital to PLIPOs, helping to bring new drugs to market (Lazonick and Tulum 2011).

Over the last 10-15 years, however, the R\&D investments of US big pharma have not been generating many new blockbuster drugs even as the 20-year patents on the last generation of drugs have been running out. In 1994, at a time when most US Old Economy research labs in industries other than pharmaceuticals had all but disappeared (Rosenbloom and Spencer 1996; Hopkins and Lazonick 2014), Rebecca Henderson (1994, p. 100) touted the exemplary corporate research of big pharma, arguing that "the longevity of pharmaceutical companies attests to a unique management competency: the ability to foster a high level of specialized knowledge within an organization, while preventing that information from becoming embedded in such a way that it permanently fixes the organization in the past, unable to respond to an ever-changing competitive environment." Yet over the past decade there has been a discussion of the "productivity crisis" in drug discovery (Pisano 2006; Cockburn 2007; Munos 2009; Lazonick and Tulum 2011; Pammolli et al. 2011; Khanna 2012; DeRuiter and Holston 2012; Graham 2014; Scannell and Bosley 2016; Lowe 2016; Gyurjyan et al. 2017). A major part of the problem, as we elaborate below, is that leading US pharmaceutical companies such as Merck and Pfizer have been spending the last two decades living off patented drugs with very little to replace them in the pipeline.

The acute problem of access to medicines, therefore, goes far beyond the actions of individuals or even companies. The Gilead problem is an American problem, and given the centrality of the US pharmaceutical industry to access to medicines around the world, the American problem is a global problem. The key cause of high drug prices, restricted access to medicines, and stifled innovation, we submit, is a social disease called "maximizing shareholder value" (MSV). Armed with "the theory of innovative enterprise," policy-makers can take steps to eradicate the MSV disease (Lazonick 2014a; Lazonick 2017a).

\section{The Theory of Innovative Enterprise and the Flaws in MSV}

MSV is a profit-driven ideology that results in high drug prices, restricted access to existing medicines, and stifled pharmaceutical innovation. If widespread access to critical medicines at affordable prices is the goal, MSV needs to be replaced by a product-driven norm of corporate governance. Underpinning this product-driven norm is "the theory of innovative enterprise" (Lazonick 2012b; Lazonick 2016b). ${ }^{9}$ The theory of innovative enterprise provides an analytical framework for understanding how a business enterprise can generate a product that is higher quality (in medicines, more effective and safer) and lower cost (more accessible and affordable) than products previously available.

The innovation process that can generate these outcomes is:

- Uncertain: When investments in transforming technologies and accessing markets are made, the product and financial outcomes cannot be known. Hence the need for strategy.

- Collective: To generate higher-quality, lower-cost products, the enterprise must integrate the skills and efforts of large numbers of people with different 
responsibilities and capabilities into the learning processes that are the essence of the innovation process. Hence the need for organization.

- Cumulative: Collective learning today enables collective learning tomorrow, and these organizational learning processes must be sustained over time until, through the sale of innovative products, financial returns can be generated. Hence the need for finance.

The theory of innovative enterprise identifies three social conditions-strategic control, organizational integration, and financial commitment - that can enable the firm to manage the uncertain, collective, and cumulative character of the innovation process.

- Strategic control: For innovation to occur in the face of technological, market, and competitive uncertainties, executives who control corporate resource allocation must have the abilities and incentives to make strategic investments in innovation. Their abilities depend on their knowledge of how strategic investments in new capabilities can enhance the enterprise's existing capabilities. Their incentives depend on alignment of their personal interests with the company's purpose of generating innovative products.

- Organizational integration: The implementation of an innovative strategy requires integration of people working in a complex division of labor into the collective and cumulative learning processes that are the essence of innovation. Work satisfaction, promotion, remuneration, and benefits are important instruments in a reward system that motivates and empowers employees to engage in collective learning over a sustained period of time.

- Financial commitment: For collective learning to cumulate over time, the sustained commitment of "patient capital" must keep the learning organization intact. For a startup company, venture capital can provide financial commitment. For a going concern, retained earnings (leveraged if need be by debt issues) are the foundation of financial commitment.

The theory of innovative enterprise explains how, in the United States during the twentieth century, a "retain-and-reinvest" allocation regime enabled a relatively small number of business enterprises in a wide range of industries to grow to employ tens, or even hundreds, of thousands of people and attain dominant product-market shares. ${ }^{10}$ Companies retained corporate profits and reinvested them in productive capabilities, including first and foremost collective and cumulative learning. Companies integrated personnel into learning processes through career employment. Into the 1980s, and in some cases beyond, the norm of a career-with-one-company prevailed at major US corporations. A steady stream of dividend income and the prospect of higher future stock prices based on innovative products gave shareholders an interest in "retain-andreinvest."

From the 1960s, however, a changing business environment encouraged executives of established US corporations to shift corporate resource allocation from "retain-and reinvest" to "downsize-and-distribute" (Lazonick 1992, Lazonick and O'Sullivan 2000, Lazonick 2009, Lazonick 2015b). ${ }^{11}$ By the 1980 s, even in good times, companies began to downsize their labor forces and distribute more profits to shareholders. Justifying this dramatic transformation in corporate resource allocation was a new ideology that taught 
that, for the sake of economic efficiency, companies should "maximize shareholder value” (Lazonick and O’Sullivan 2000; Lazonick 2014a; Lazonick 2017a).

The MSV argument is that, of all participants in the corporation, only shareholders make productive contributions without a guaranteed return (Jensen 1986). All other participants - among them, creditors, workers, suppliers, and distributors - allegedly receive a market-determined price for the goods or services they render to the corporation, and hence take no risk of whether the company makes or loses money. On this assumption, only shareholders, as the sole risk-takers, have an economically justifiable claim to profits.

A fundamental flaw in MSV lies in the erroneous assumption that shareholders are the only corporate participants who bear risk. Taxpayers through government agencies and workers through the firms that employ them make risky investments in productive capabilities on a regular basis. Households, as taxpayers and workers, may have legitimate economic claims on the distribution of profits.

A prime example of how taxpayers invest without a guaranteed return can be found at the NIH, which from 1938 through 2016 spent just a shade under \$1 trillion in 2016 dollars on life-sciences research (National Institutes of Health 2016). Drug companies benefit from the knowledge that the NIH generates. As risk bearers, taxpayers fund investments in the knowledge base - as well as physical infrastructure such as roads-required by business, and hence have tax claims on corporate profits. But because profits may not be forthcoming and tax rates can be changed, the returns to taxpayers' investments are not guaranteed (Hopkins and Lazonick 2014).

Through the application of skill and effort, workers regularly make productive contributions to the company's future products, and hence prospective profits. "Retainand-reinvest" rewards innovative workers. Their rewards take the forms of continued employment and career advancement. But these careers can be diminished because of the layoffs that reflect product failures or transformations in strategic control (Lazonick and Shin 2017). Profits from innovation may not materialize, and even when they do, "downsize-and distribute" may deny these workers shares of profits that, as risk-bearers, they should have received. Hence workers invest in collective and cumulative learning without guaranteed returns.

As risk bearers, therefore, taxpayers whose money supports business enterprises and workers whose efforts generate productivity improvements have claims on corporate profits if and when they occur. MSV ignores the risk-reward relation for these two types of economic actors in the operation and performance of business corporations.

Indeed, another basic flaw in MSV is that the public shareholders whom it holds up as the only risk bearers typically do not invest in the company's value-creating capabilities. Rather, as savers or speculators, they buy outstanding shares on the smarket for the sake of dividends and stock-price gains. Public shareholders generally make no productive contributions to the enterprise. Indeed, from 2007 through 2016, net equity issues in the United States were over four trillion dollars in the negative; US corporate treasuries fund public shareholders rather than vice versa. ${ }^{12}$ 
The proponents of MSV (see Jensen 1986; Jensen and Murphy 1990) advocate that, through stock-based pay, senior executives should be incentivized to "disgorge" corporate earnings as buybacks and dividends to the corporate participants who matter least-just the opposite of the financial commitment needed for innovation. These distributions to shareholders generally come at the expense of the stable and remunerative career opportunities that integrate employees into processes of collective and cumulative learning. As for strategic control, a senior executive who sees MSV as the key to corporate success has lost not only the incentive but probably also the ability to allocate corporate resources to potentially innovative investments. In sum, MSV undermines investments in innovation that, when successful, yield products that are higher quality and lower cost than previously available.

Major US pharmaceutical companies have the MSV disease, as evidenced by not only massive stock buybacks and exploding executive pay but also the "productivity crisis" in drug discovery, mentioned above. Companies such as Merck and Pfizer have spent the last two decades living off patented blockbuster drugs, with very little to replace them in the pipeline (Phillips 2013; McGrath 2014a; McGrath 2014b). In the name of MSV, they have been profit-driven. For a company to be an innovative enterprise, however, it needs to be product-driven.

Pfizer's focus on profits before products began before the 1980s. In the case of Merck, with Roy Vagelos as head of research from 1975 to 1985 and as CEO for the following decade, the company remained highly innovative through investments in organizational learning (Hawthorne 2003; Vagelos and Galambos 2004). In the decade that Vagelos headed Merck, the company generated both innovative products and high profits, with profit margins at over 20 percent for 1985-1994. The gains from innovation enabled Merck to provide its drug for river blindness for free to millions of poor people around the world (Vagelos and Galambos 2004, pp. 251-253).

But, as shown in Table 6, high profits also permitted the company to do substantial stock buybacks on top of dividends at a time when MSV was becoming the unchallenged governance ideology in corporate America. Once Vagelos stepped down as Merck CEO, innovation largely stopped at the company. According to a number of Merck insiders, his successor Raymond Gilmartin stifled research (Hawthorne 2006, p. 30), and, as suggested by the decadal figures on distributions to shareholders shown in Table 6, under CEOs Richard Clark (2005-2010) and Kenneth Frazier (from 2011) the financialization of Merck has only gotten worse. Since Frazier took over, Merck's revenues have fallen from $\$ 46.0$ billion to $\$ 39.8$ billion, and employment from 94,000 to 68,000 . Yet from 2011 through 2016, during Frazier's reign as CEO, Merck did \$26.4 billion in buybacks, representing 102 percent of net income and dividends another 120 percent. ${ }^{13}$ As shown in Table 7, a prime beneficiary of these distributions to shareholders was CEO Frazier, whose total compensation in 2016 was $\$ 38.6$ million, of which 76 percent was stock based. 
Table 6. Stock buybacks, cash dividends, and R\&D, Merck and Pfizer, 1975-2016

\begin{tabular}{|l|r|r|r|r|r|r|}
\hline Merck & $\begin{array}{c}\text { BB } \\
\text { \$b }\end{array}$ & $\begin{array}{c}\text { DV } \\
\text { \$b }\end{array}$ & BB/NI\% & DV/NI\% & $\begin{array}{c}\text { (BB+DV)/ } \\
\text { NI\% }\end{array}$ & \multicolumn{1}{|c|}{$\begin{array}{c}\text { R\&D/ } \\
\text { Sales } \%\end{array}$} \\
\hline $\mathbf{1 9 7 5 - 1 9 8 4}$ & 0.4 & 1.6 & 9.7 & 44.8 & 54.5 & 9.4 \\
\hline $\mathbf{1 9 8 5 - 1 9 9 4}$ & 4.8 & 7.3 & 30.3 & 46.1 & 76.5 & 10.8 \\
\hline $\mathbf{1 9 9 5 - 2 0 0 4}$ & 26.4 & 25.8 & 46.4 & 45.5 & 91.8 & 7.9 \\
\hline $\mathbf{2 0 0 5 - 2 0 1 4}$ & 26.5 & 42.2 & 51.6 & 82.2 & 133.8 & 19.1 \\
\hline $\mathbf{2 0 1 5}$ & 4.2 & 5.1 & 94.2 & 115.2 & 209.4 & 16.7 \\
\hline $\mathbf{2 0 1 6}$ & 3.4 & 5.1 & 87.6 & 130.7 & 218.3 & 25.4 \\
\hline & BB & DV & & & (BB+DV)/ & R\&D/ \\
Pfizer & \$b & \$b & BB/NI\% & DV/NI\% & NI\% & Sales $\%$ \\
\hline $\mathbf{1 9 7 5 - 1 9 8 4}$ & 0.0 & 1.2 & 0.0 & 43.1 & 43.1 & 5.5 \\
\hline $\mathbf{1 9 8 5 - 1 9 9 4}$ & 3.2 & 4.0 & 41.7 & 51.4 & 93.1 & 10.5 \\
\hline $\mathbf{1 9 9 5 - 2 0 0 4}$ & 34.5 & 21.9 & 71.6 & 45.6 & 117.2 & 17.8 \\
\hline $\mathbf{2 0 0 5 - 2 0 1 4}$ & 60.8 & 66.6 & 52.3 & 57.3 & 109.5 & 15.5 \\
\hline $\mathbf{2 0 1 5}$ & 6.2 & 6.9 & 88.5 & 99.7 & 188.2 & 15.7 \\
\hline $\mathbf{2 0 1 6}$ & 5.0 & 7.3 & 69.3 & 101.4 & 170.7 & 14.9 \\
\hline
\end{tabular}

$\mathrm{REV}=$ revenues; $\mathrm{NI}=$ Net Income; $\mathrm{BB}=$ stock buybacks (aka repurchases); $\mathrm{DV}=$ cash dividends; $\mathrm{R} \& \mathrm{D}=$ research and development expenditures

Sources: S\&P Compustat database and company 10-K SEC filings

Table 7. Total actual realized gains (ARG) compensation, 2007-2016, of Kenneth C. Frazier (Merck CEO from 2011), and Ian C. Read (Pfizer CEO since 2011), and percentage of total pay that was stock-based

\begin{tabular}{|c|c|c|c|c|}
\hline & $\begin{array}{c}\text { Kenneth C. Frazier Total } \\
\text { ARG pay, \$m }\end{array}$ & $\begin{array}{c}\text { \% stock- } \\
\text { based }\end{array}$ & $\begin{array}{c}\text { Ian C. Read } \\
\text { Total ARG pay, \$m }\end{array}$ & $\begin{array}{c}\text { \% stock- } \\
\text { based }\end{array}$ \\
\hline $\mathbf{2 0 0 7}$ & 4.4 & 31 & 3.8 & 41 \\
\hline $\mathbf{2 0 0 8}$ & 5.4 & 49 & 4.2 & 16 \\
\hline $\mathbf{2 0 0 9}$ & 4.8 & 26 & 6.4 & 15 \\
\hline $\mathbf{2 0 1 0}$ & 7.8 & 33 & 15.2 & 9 \\
\hline $\mathbf{2 0 1 1}$ & 8.6 & 15 & 14.9 & 17 \\
\hline $\mathbf{2 0 1 2}$ & 10.1 & 17 & 18.3 & 31 \\
\hline $\mathbf{2 0 1 3}$ & 10.3 & 58 & 16.7 & 59 \\
\hline $\mathbf{2 0 1 4}$ & 21.2 & 59 & 28.0 & 63 \\
\hline $\mathbf{2 0 1 5}$ & 18.8 & 49 & 23.0 & 56 \\
\hline $\mathbf{2 0 1 6}$ & 38.6 & 76 & 23.7 & 72 \\
\hline $\mathbf{2 0 0 7 - 2 0 1 6}$ & $\mathbf{1 2 9 . 9}$ & 52 & $\mathbf{1 5 4 . 2}$ & 52 \\
\hline
\end{tabular}

Source: S\&P ExecuComp database (data retrieved July 31, 2017)

In November 2015, Pfizer commanded attention for its plan to avoid US corporate taxation by making Ireland its tax home through the acquisition of Allergan, itself a former US-based company that had recently made Dublin its global headquarters. Pfizer CEO Ian Read moaned in a media interview that Pfizer's US tax bill put the company at a "tremendous disadvantage" in global competition. "We're fighting," he said in the interview, "with one hand tied behind our back" (Rockoff et al. 2015). Yet from 2011 through September 2015, with Read as CEO, Pfizer's distributions to shareholders were 4.7 times its US tax payments. If they really consider Pfizer to be cash-constrained, therefore, Read and his board should question why they did $\$ 45$ billion in buybacks in 2011-2015. Perhaps it was the golden handcuffs of stock-based pay; over the years 2011 through 2016 Read's total annual compensation averaged \$20.8 million, of which 52 percent was from options and awards (see Table 7). 
Pfizer's revenues fell from $\$ 67.8$ billion in 2010 to $\$ 52.8$ billion in 2016 , mainly because of the expiration of patents on some of the company's blockbuster drugs. Meanwhile, employment was slashed from 110,600 in 2010 to around 78,000 in 2013 and 2014, although it increased to 96,500 in 2016 with the acquisition of Hospira and its workforce of 19,000 (Terry 2015). Pfizer has long since lost the capability to generate its own drug products. Since 2001 the company has launched only four internally developed products, the last one in 2005. Driven by profits rather than products, Pfizer has been, for even longer than Merck, the antithesis of an innovative enterprise.

\section{How to Fix US Pharma's Broken Business Model}

In our view, a primary policy objective of all government agencies, civil-society organizations, and business enterprises that seek innovative and affordable drugs should be the eradication of MSV as an ideology of corporate governance. Promulgated in the name of "value creation," MSV is actually an ideology of value extraction. MSV is a global problem, but the US pharmaceutical industry is where the ideology operates unconstrained. Here, briefly, are steps that the US government can take to bring the MSV disease under control:

- Ban pharmaceutical companies from doing stock repurchases in particular and excessive distributions to shareholders in general. Such a ban would go a long way to restoring stable and equitable growth to the US economy and would encourage a focus on access to medicines in the pharmaceutical industry (Lazonick 2016a). ${ }^{14}$

- Structure executive compensation to reward the success of the pharmaceutical company in generating new medicines at affordable prices. Stock-based compensation rewards executives for draining earnings out of the company rather than mobilizing earnings to invest in innovation (Lazonick 2016c).

- Place stakeholders representing households as taxpayers, workers, and consumers on boards of directors of publicly listed pharmaceutical companies, along with shareholders who represent households as savers. Exclude from boards predatory value extractors (Lazonick and Shin 2017).

- Regulate the price of any drug that has benefited from government funding, subsidies, and protection (however far upstream in the innovation process) with a view to making such drugs accessible to the largest number of people who need them at the most affordable prices. This regulatory approach would, in effect, treat a pharmaceutical drug like a public utility (Trouiller et al. 2001; Quigley 2017).

- Increase the returns to households as taxpayers for their investments in life-sciences research. The Bayh-Dole Act of 1980, which facilitates commercialization of federally funded research, has given away too many of the benefits of taxpayerfunded research to business interests, including the private interests of university scientists, who can make fortunes in the commercialization process. Within the university, the pursuit by "star scientists" of individual gain from publicly funded research often undermines the collective and cumulative learning that medical research requires (Wright 1986; Krimsky 2003).

- Use government funding, in collaboration with innovative businesses, to ensure the "collective and cumulative careers" of life-science researchers, who are the lowestpaid PhDs in the natural sciences (Lazonick et al. 2014, Hopkins and Lazonick 2014; Lazonick 2017b). There is evidence that the doubling of the NIH budget between 
1998 and 2003 created large cohorts of life-science PhDs while contributing to an even-more-financialized biomedical-industrial complex within which the prospects of collective and cumulative careers became more insecure (Teitelbaum 2008; Cyranoski et al. 2011; Teitelbaum 2014; Lazonick et al. 2014; Stephan 2015; Lazonick 2017b).

It is folly that the US government provides drug companies with NIH funding, patent protection, and, under the Orphan Drug Act, market exclusivity but does not regulate drug prices. In testimony to the US Congress, Rohit Malpani (2015), MSF Director of Policy and Analysis, countered the drug companies' contention that higher prices generate profits that are reinvested in new drug development by arguing that "the sole reliance on high medicine prices, backed by monopolies, is a flawed paradigm for funding innovation" that:

leads to unaffordable prices while failing to stimulate innovation for diseases disproportionately affecting developing countries, where patients have limited purchasing power. Our current innovation model is also failing patients in developed countries, as with antibiotic resistance. In spite of the need for new antibiotics, pharmaceutical companies, including Pfizer, the world's largest, have abandoned antibiotic drug development. Since antibiotics must be affordable and used sparingly, the industry response has been to withdraw (Malpani 2015).

We agree. Companies that are concerned with profits, not products, tend to be uninterested in allocating resources to the development of drugs that promise low profit margins. When the US government has sought to regulate drug prices, pharmaceutical companies have argued that they need high prices to fund investments in innovation. The fact is, however, that the largest drug companies allocate all of their profits and more to buybacks and dividends. Legitimized by MSV, "downsize-and-distribute" has enabled the senior pharma executives who make these resource-allocation decisions to secure enormous compensation for themselves.

The innovative drugs that are available are unaffordable, while innovative drugs that hundreds of millions of people need are unavailable. Considering its terrible performance in the name of MSV, and its dependence on government for life-sciences research, market protection, and product demand, the US pharmaceutical sector is in need of a corporate-governance revolution. Aided by government regulation and progressive social norms, US pharmaceutical companies need to reject MSV and begin a transformation to innovative enterprise. The first step is a dramatic change in the types of pharmaceutical executives - including their abilities and incentives - who occupy positions of strategic control. 
References:

Andersson, T., P. Gleadle, C. Haslam, and N. Tsitsianis (2010), "Bio-Pharma: A Financialized Business Model," Critical Perspectives on Accounting, 21, 7: 631-641.

Board of Governors of the Federal Reserve System (2016), Federal Reserve Statistical Release Z.1, "Financial Accounts of the United States: Flow of Funds, Balance Sheets, and Integrated Macroeconomic Accounts," Table F-223: Corporate Equities, June 9, at http://www.federalreserve.gov/releases/z1/current/.

Cha, A., (2015), "Drug and biotech industry trade groups give Martin Shkreli the boot," Washington Post, September 24.

Citizens for Tax Justice (2016), "Fortune 500 companies hold a record \$2.4 trillion offshore," March 3, at http://ctj.org/pdf/pre0316.pdf.

Cockburn, I. (2007), "Is the Pharmaceutical Industry in a Productivity Crisis?" in J. Lerner and S. Stern, eds., Innovation Policy and the Economy, Volume 7, MIT Press: 1-32.

Cookson, C. (2014), "Raymond Schinazi fled Nasser's Egypt to become a pioneer in antivirals," Financial Times, July 27.

Cyranoski, D., N. Gilbert, H. Ledford, A. Nayar and M. Yahia (2011), "Education: The PhD factory: The world is producing more PhDs than ever before. Is it time to stop?" Nature, 472: 276-279.

DeRuiter, J., and P. Holston (2012), "Drug Patent Expirations and the 'Patent Cliff'," U.S. Pharmacist, 37, 6: 12-20.

Ernst \& Young, (2016), Beyond Borders: Returning to Earth, Biotechnology Report 2016, at http://www.ey.com/Publication/vwLUAssets/EY-beyond-borders-2016/\$FILE/EY-beyondborders-2016.pdf

Fick, M., and B. Hirschler (2014), "Gilead offers Egypt new hepatitis C drug at 99 percent discount," Reuters, March 21, at http://www.reuters.com/article/us-hepatitis-egypt-gileadsciences-idUSBREA2K1VF20140321.

Graham, J. (2014), "Crisis in Pharma R\&D," Forbes, November 26, at https:/www.forbes.com/sites/theapothecary/2014/11/26/crisis-in-pharma-rd-it-costs-2-6billion-to-develop-a-new-medicine-2-5-times-more-than-in-2003/\#43a94bc9321c.

Gyurjyan, G, S. Thaker, K. Westhues, and C. Zwaanstra (2017), "Rethinking pharma productivity," McKinsey \& Company, January, at http://www.mckinsey.com/industries/pharmaceuticals-and-medical-products/ourinsights/rethinking-pharma-productivity.

Hawthorne, F. (2003), The Merck Druggernaut: The Inside Story of a Pharmaceutical Giant, John Wiley \& Sons.

Hawthorne, F. (2006), "Merck's Fall from Grace," The Scientist, 20, 5.

Henderson, N. and M. Schrage (1984), "The roots of biotechnology: Government R\&D spawns a new industry," Washington Post, December 16.

Henderson, R. (1994), "Managing Innovation in the Information Age," Harvard Business Review, January-February: 100-107,

Hopkins, M., and W. Lazonick (2014), "Who Invests in the High-Tech Knowledge Base?" Institute for New Economic Thinking Working Group on the Political Economy of Distribution Working Paper No. 6, September (revised December 2014), at http://ineteconomics.org/ideaspapers/research-papers/who-invests-in-the-high-tech-knowledge-base.

Hopkins, M., and W. Lazonick (2016), "The Mismeasure of Mammon: The Uses and Abuses of the Executive Pay Data," Institute of New Economic Thinking Working Paper No. 49, August, at https://www.ineteconomics.org/research/research-papers/the-mismeasure-of-mammon-usesand-abuses-of-executive-pay-data.

Horowitz, M. (1987), "Interview with Rep. Henry A. Waxman, Chairman, Subcommittee on Health and the Environment, U.S. House of Representatives," HealthWeek, September 28. Horwitz, S. (1985), "Drug industry accused of gouging public," Washington Post, July 16. 
Jensen, M. (1986), “Agency Costs of Free Cash Flow, Corporate Finance, and Takeovers," American Economic Review, 76, 2: 323-329.

Jensen, M., and K. Murphy (1990), "Performance Pay and Top Management Incentives," Journal of Political Economy, 98, 2, 1: 225-264.

Kantarjian, H., and S. Rajkumar (2015), "Why Are Cancer Drugs So Expensive in the United States, and What Are the Solutions?" Mayo Clinic Proceedings, April: 500-504, at http://www.mayoclinicproceedings.org/article/S0025-6196(15)00101-9/abstract.

Khanna, I. (2012), "Drug Discovery in Pharmaceutical Industry: Challenges and Trends," Drug Discovery Today, 17, 19/20.

Kravitz, R. (1985), "Prescription drug industry accused of price gouging," The Record, July 16.

Krimsky, S. (2003), Science in the Private Interest: Has the Lure of Profits Corrupted Biomedical Research? Rowan and Littlefield.

Langreth, R., and D. Armstrong, (2015), “Clinton's tweet on high drug prices sends biotech stocks down," BloombergBusiness, September 21.

Lazonick, W. (1992), "Controlling the Market for Corporate Control: The Historical Significance of Managerial Capitalism," Industrial and Corporate Change, 1, 3: 445-488.

Lazonick, W. (2009), Sustainable Prosperity in the New Economy? Business Organization and High-Tech Employment in the United States, Upjohn Institute for Employment Research.

Lazonick, W. (2012a), "Alfred Chandler's Managerial Revolution," in W. Lazonick and D. Teece, eds., Management Innovation: Essays in the Spirit of Alfred D. Chandler, Jr., Oxford University Press: 3-29.

Lazonick, W. (2012b), “The Theory of Innovative Enterprise: Methodology, Ideology, and Institutions," in J. Moudud, C. Bina and P. Mason, eds., Alternative Theories of Competition: Challenges to the Orthodoxy, Routledge: 127-159.

Lazonick, W. (2014a), "Innovative Enterprise and Shareholder Value," Law and Financial Markets Review, 8, 1: 52-64.

Lazonick, W. (2014b), "Profits Without Prosperity: Stock Buybacks Manipulate the Market and Leave Most Americans Worse Off," Harvard Business Review, September: 46-55.

Lazonick, W. (2014c), "Taking Stock: Why Executive Pay Results in an Unstable and Inequitable Economy," Roosevelt Institute White Paper, June 5, at http://rooseveltinstitute.org/takingstock-why-executive-pay-results-unstable-and-inequitable-economy/.

Lazonick, W. (2015a), "Buybacks: From Basics to Politics,” AIR Special Report, The AcademicIndustry Research Network, August 1, at http://www.theairnet.org/v3/backbone/uploads/2015/08/Lazonick-Buybacks-Basics-to-Politics20150819.pdf.

Lazonick, W. (2015b), "Stock Buybacks: From Retain-and-Reinvest to Downsize-and-

Distribute," Center for Effective Public Management, Brookings Institution, April 17, at

http://www.brookings.edu/research/papers/2015/04/17-stock-buybacks-lazonick.

Lazonick, W. (2015c), "The Theory of Innovative Enterprise: Foundation of Economic Analysis," AIR Working Paper, August, at http://www.theairnet.org/v3/backbone/uploads/2015/08/Lazonick.TIE-Foundations AIRWP13.0201.pdf.

Lazonick, W. (2016a), "How Stock Buybacks Make Americans Vulnerable to Globalization," paper presented to the Conference on Mega-Regionalism: New Challenges for Trade and Innovation, East-West Center, Honolulu, January 20.

Lazonick, W. (2016b), "Innovative Enterprise or Sweatshop Economics? In Search of Foundations of Economic Analysis," Challenge, 59, 2: 65-114.

Lazonick, W. (2016c), "The Value-Extracting CEO: How Executive Stock-Based Pay Undermines Investment in Productive Capabilities," Institute for New Economic Thinking Working Paper No. 54, at https://www.ineteconomics.org/research/research-papers/the-valueextracting-ceo-how-executive-stock-based-pay-undermines-investment-in-productivecapabilities. 
Lazonick, W. (2017a), "The Functions of the Stock Market and the Fallacies of Shareholder Value," Institute for New Economic Thinking Working Paper No. 58, June, at https://www.ineteconomics.org/research/research-papers/the-functions-of-the-stock-marketand-the-fallacies-of-shareholder-value.

Lazonick, W. (2017b), "Marketization and Financialization: How the U.S. New Economy Business Model Has Devalued Science and Engineering PhDs," Institute for New Economic Thinking Perspectives, May 9, at https://www.ineteconomics.org/perspectives/blog/marketization-and-financialization.

Lazonick, W., and M. O'Sullivan (2000), "Maximizing Shareholder Value: A New Ideology for Corporate Governance," Economy and Society, 29, 1: 13-35.

Lazonick, W., and M. Sakinç (2010), "Do Financial Markets Support Innovation or Inequity in the Biotech Drug Development Process?" paper presented at the Conference on Innovation and Inequality: Pharma and Beyond, Pisa, Italy, May 15.

Lazonick, W., and J. Shin (2017), Rebalancing Value Creation and Value Extraction: How to Deactivate Hedge Funds and Recreate Sustainable Prosperity, Report to the Korea Economic Research Institute, May 31.

Lazonick, W., and Ö. Tulum (2011), "US Biopharmaceutical Finance and the Sustainability of the Biotech Business Model," Research Policy, 40, 9: 1170-1187.

Lazonick, W., M. Hopkins, and Ö. Tulum (2015), "Tax dodging just one part of Pfizer's corrupt business model," Huffington Post, December 4, at http://www.huffingtonpost.com/williamlazonick/tax-dodging-just-one-part b 8721900.html.

Lazonick, W., P. Moss, H. Salzman, and Ö. Tulum (2014), "Skill Development and Sustainable Prosperity: Collective and Cumulative Careers versus Skill-Biased Technical Change," Institute for New Economic Thinking Working Group on the Political Economy of Distribution Working Paper No. 7, December 2014, at http://ineteconomics.org/ideas-papers/researchpapers/skill-development-and-sustainable-prosperity-cumulative-and-collective-careers-versusskill-biased-technical-change.

Leary, W. (1995), "U.S. gives up right to control drug prices," New York Times, April 12.

Levin, A. (2001), "Myth of the High Cost of Drug Research," Center for Medical Consumers, August 1, at https://medicalconsumers.org/2001/08/01/myth-of-the-high-cost-of-drug-research/. Lowe, D. (2016), "Productivity Over the Years," Science Translational Medicine, October 14, at http://blogs.sciencemag.org/pipeline/archives/2016/10/14/productivity-over-the-years.

Malpani, R. (2015), "MSF's Oral Testimony to the United States House of Representatives Committee on Ways and Means," Hearing on Access to Medicines, U.S. House of

Representatives, December 8, at http://www.msfaccess.org/content/msfs-oral-testimony-unitedstates-house-representatives-committee-ways-and-means.

Mazzucato, M. (2016), "High Cost of New Drugs: Why Government Must Negotiate a Better

Deal for Publicly Funded Research," BMJ, 354, i4136, at

http://www.bmj.com/content/354/bmj.i4136.

McGrath, M. (2014a), "Drug patent expirations continue to hit Pfizer revenue," Forbes, January 28.

McGrath, M. (2014b), "Merck sales slide on expiring drug patents but shares lifted by cancerfighting collaboration," Forbes, February 5.

Médecins Sans Frontières (2015), "The Cost of Medicine: A Special Report," Alert, Fall, at http://www.doctorswithoutborders.org/article/alert-special-report-cost-medicine

Montalban, M., and M. Sakinç (2013), "Financialization and Productive Models in the Pharmaceutical Industry," Industrial and Corporate Change, 22, 4: 981-1030.

Mossinghoff, G. (1999), "Overview of the Hatch-Waxman Act and Its Impact on the Drug Development Process," Food and Drug Law Journal, 54: 187-194.

Munos, B. (2006), “Can Open-Source R\&D Reinvigorate Drug Research?” Nature Reviews Drug Discovery, 5, 9: 723-729.

Munos, B., (2009), "Lessons from 60 years of pharmaceutical innovation," Nature Reviews, Drug Discovery, 8, 12: 959-968. 
National Institutes of Health (2016), Budget, at https://www.nih.gov/about-nih/what-wedo/budget.

Nightingale, P., and P. Martin (2004), "The Myth of the Biotech Revolution," TRENDS in Biotechnology, 22, 11: 564-569.

Nordrum, A. (2015), "Why are prescription drugs so expensive? Big Pharma points to the cost of research and development, Critics say that's no excuse," International Business Times, September 19.

Pammolli, F., L. Magazzini, and M. Riccaboni (2011), "The Productivity Crisis in Pharmaceutical R\&D," Nature Reviews, Drug Discovery, 10, 6: 428-438.

Phillips, D. (2013), "Pfizer's pipeline story begins to unravel," YCharts, August 30, at https://ycharts.com/analysis/story/pfizers pipeline turnaround story begins to unravel.

Pisano, G. (2006), Science Business: The Promise, the Future, and the Reality of Biotech, Harvard Business School.

Pollack, A. (1988), "The troubling cost of drugs that offer hope," New York Times, February 9.

Pollack, A. (2015), "Drug goes from $\$ 13.50$ a tablet to $\$ 750$, overnight," New York Times, September 20.

Quigley, F. (2017), “Should we treat pharma as a public utility?” Truthout, May 18, at http://www.truth-out.org/opinion/item/40610-should-we-treat-pharma-as-a-public-utility.

Rockoff, J., D. Mattioli, and D. Cimilluca (2015), "Pfizer and Allergan begin merger talks," Wall Street Journal, October 29, at https://www.wsj.com/articles/pfizer-allergan-consideringcombining-1446079506

Rosenbloom, R., and W. Spencer, eds. (1996), Engines of Innovation: U.S. Industrial Research at the End of an Era, Harvard Business School Press.

Rovner, J. (1992), "Should the government regulate prescription drug prices," CQ Researcher, July 17.

Roy, V. and L. King (2016), "Betting on Hepatitis C: How Financial Speculation in Drug Development Influences Access to Medicines," BMJ, 354: i3718, at http://www.bmj.com/content/354/bmj.i3718.

Rubin, R, (2015), "\$2.1 trillion overseas to avoid taxes," BloombergBusiness, March 4.

Sachs, J. (2015), "Gilead's greed that kills," Huffington Post, July 27, at http://www.huffingtonpost.com/jeffrey-sachs/gileads-greed-that-kills b 7878102.html.

Sakinç, M., and Ö. Tulum (2012), "Innovation versus Financialization in the Biopharmaceutical Industry: The PLIPO Business Model," paper presented at the at the Ford Foundation Conference on Finance, Business Models, and Sustainable Prosperity, New York City, New York, December 6 and 7.

Scannell, J., and J. Bosley (2016), “When Quality Beats Quantity: Decision Theory, Drug Discovery, and the Reproducibility Crisis," PLOS ONE, February 10, at http://journals.plos.org/plosone/article?id=10.1371/journal.pone.0147215.

Scannell, J., A. Blanckley, H. Boldon, and B. Warrington (2012), "Diagnosing the Decline in Pharmaceutical R\&D Efficiency," Nature Reviews Drug Discovery, 11, 3: 191-200.

Stephan, P. (2015), How Economics Shapes Science, Harvard University Press.

Teitelbaum, M. (2008), "Structural Disequilibria in Biomedical Research," Science, 321, 5889: 644-645.

Teitelbaum, M. (2014), Falling Behind? Boom, Bust, and the Global Race for Scientific Talent, Princeton University Press.

Terry, M. (2015), "Hospira employees nervous as Pfizer (PFE) aims to cut $\$ 800$ million in costs," BioSpace, February 9, at http://www.biospace.com/News/hospira-employees-nervous-as-pfizeraims-to-cut $/ 363908$.

The Staffs of Senators Ron Wyden and Charles E. Grassley (2015), "The Price of Sovaldi and Its Impact in the U.S. Health Care System," Committee on Finance, United States Senate, December 1, p. 117, at http://www.finance.senate.gov/ranking-members-news/wyden-grassleysovaldi-investigation-finds-revenue-driven-pricing-strategy-behind-84-000-hepatitis-drug. 
Trouiller, P., E. Torreale, P. Olliaro, N. White, S. Foster, D. Wirth, and B. Pécoul (2001), "Drugs for neglected diseases: A failure of the market and a public health failure," Tropical Medicine and International Health, 6, 11: 945-951.

Tulum, Ö. (2017), "Financialization versus Innovation: An Analysis of the Sources of Innovation in European Big Pharma," paper prepared for the European Commission Project on InnovationFuelled, Sustainable and Inclusive Growth, University of Ljubljana, May.

UK Department of Health (2012), The Pharmaceutical Price Regulation Scheme - Eleventh Report to Parliament, February, at https://www.gov.uk/government/publications/pharmaceutical-price-regulation-scheme-11threport-to-parliament.

Umemura, M. (2010), “Reconsidering Japan's Underperformance in Pharmaceuticals: Evidence from Japan's Anticancer Drug Sector," Enterprise and Society, 11, 3: 560-593.

United States Census Bureau (2016), "Statistics of U.S. Businesses," data on "U.S., NAICS sectors, larger employment sizes" at http://www.census.gov/econ/susb/.

United States Senate Committee on Finance (2015), "Wyden-Grassley Sovaldi investigation finds revenue-driven pricing strategy behind $\$ 84,000$ hepatitis drug," Press release, December 1 at http://www.finance.senate.gov/ranking-members-news/wyden-grassley-sovaldi-investigationfinds-revenue-driven-pricing-strategy-behind-84-000-hepatitis-drug.

Vagelos, R., and L. Galambos (2004), Medicine, Science, and Merck, Cambridge University Press.

Wright, S. (1986), "Recombinant DNA Technology and Its Social Transformation, 1972-1982," Osiris, $2^{\text {nd }}$ ser., 2: 303-360.

\section{NOTES}

An earlier version of parts of this paper appeared as a chapter in David Tyfield, Rebecca Lave, Samuel Randalls, and Charles Thorpe, eds., The Routledge Handbook of the Political Economy of Science, Routledge, 2017. This version provides updated data and elaborates certain parts of the argument. Both versions draw upon our two contributions to the United Nations Secretary-General's High-Level Panel on Access to Medicines: http://www.unsgaccessmeds.org/list-of-contribution/

1 Under US Securities and Exchange Commission Rule 10b-18, which governs the conditions under which a corporation can be charged with stock-price manipulation in doing open-market repurchases, companies do not disclose the days on which they are doing open-market repurchases (Lazonick 2015b).

2 We begin the series in 2006 because of changes in the availability of relevant executive-pay data in that year. See Hopkins and Lazonick 2016. These data were updated by Matt Hopkins from ExecuComp on July 31, 2017, at which time complete data on executive pay for fiscal 2016 were not yet available.

3 "Harvoni vs. Sovaldi: A side-by-side comparison," healthline, at http://www.healthline.com/health/hepatitis-c/harvoni-vs-sovaldi\#overview1.

4 "FDA approves Epclusa for treatment of chronic Hepatitis C virus infection,"' FDA News Release, June 28, 2016, at https:/www.fda.gov/newsevents/newsroom/pressannouncements/ucm508915.htm.

5 For an analysis of the relation between financialization and Gilead's drug pricing, see Roy and King (2016).

6 In March 2014, Gilead granted Egypt the price of $\$ 900$ for a 12-week treatment of Sovaldi. See Fick and Hirschler (2014). One suspects that the pricing concession to Egypt was a condition of the deal that Pharmasset founder Raymond Schinazi, who was originally from Egypt, made with Gilead in the 2011 sale of Pharmasset. See Cookson (2014). Under Congressional scrutiny and with revenues rolling in, Gilead extended that price to other low-income nations. As of August 2015, Gilead had made a 12-week 
treatment of Sovaldi available in 101 countries for $\$ 900$, see:

(http://www.gilead.com/ /media/files/pdfs/other/hcv\%20access\%20fact\%20sheet\%20\%20101615.pdf).

7 On innovation, speculation, and manipulation as drivers of stock-price performance, see Lazonick, (2017a).

8 As these things go, Berg himself would be appointed to Gilead's board in 1998, and, as revealed by insider trading data filed on SEC Form 4, as a company director from 2004 to 2011 he regularly exercised his stock options, netting an average of $\$ 2.9$ million per year.

9 The "theory of innovative enterprise" builds upon a wide range of studies on the social conditions that support innovation at the national, industry, and company levels (see www.theAIRnet.org).

10 Over the last century, large corporations have dominated the US economy. In 2012, the 1,909 companies with 5,000 or more employees in the United States were only 0.03 percent of all firms, but, with an average employment of 20,366, employed 34 percent of the US business-sector labor force while covering 38 percent of all payroll expenditures and generating 44 percent of all revenues. See United States Census Bureau (2016).

11 These changes included the failure of the conglomerate movement of the 1960s, Japanese competition, the rise of Silicon Valley startups, and the transformation of Wall Street from investing in companies to trading in their securities. See Lazonick (1992); Lazonick and O'Sullivan (2000); Lazonick (2009); Lazonick (2012a); Lazonick (2014a); On the pharmaceutical industry, see Lazonick and Tulum (2011).

12 Board of Governors of the Federal Reserve System (2016). Net equity issues are all corporate stock issues minus those shares withdrawn from the market through stock repurchases and merger-andacquisition activity.

13 We have recalculated Merck's reported net income in 2014 to exclude a gain of $\$ 11.4$ billion from the sale of a business that Merck recorded as an offset to expenses. Compensation data are from the company's DEF 14A (proxy statement) filings with the US Securities and Exchange Commission.

${ }^{14}$ A number of prominent US politicians, including Senator Tammy Baldwin (D-WI), former VicePresident Joseph Biden, and Senator Elizabeth Warren (D-MA), are outspoken critics of stock buybacks, and Senator Baldwin has been active in questioning the US Securities and Exchange Commission about why it permits them. See Lazonick (2016a). See also the website of the AcademicIndustry Research Network: www.theAIRnet.org. Ken Jacobson and William Lazonick are writing a history of how the SEC adopted Rule 10b-18 in November 1982, giving US corporate executives license to do massive buybacks without fear of being charged with manipulating the company's stock price. 